\title{
The Rhizobium leguminosarum bv. trifolii RosR: Transcriptional Regulator Involved in Exopolysaccharide Production
}

\author{
Monika Janczarek and Anna Skorupska \\ Department of General Microbiology, University of M. Curie-Skłodowska, Akademicka 19, 20-033 Lublin, Poland
}

Submitted 19 October 2006. Accepted 4 March 2007.

\begin{abstract}
The acidic exopolysaccharide is required for the establishment of symbiosis between the nitrogen-fixing bacterium Rhizobium leguminosarum bv. trifolii and clover. Here, we describe RosR protein from $R$. leguminosarum bv. trifolii 24.2, a homolog of transcriptional regulators belonging to the family of Ros/MucR proteins. $R$. leguminosarum bv. trifolii RosR possesses a characteristic $\mathrm{Cys}_{2} \mathrm{His}_{2}$ type zincfinger motif in its C-terminal domain. Recombinant (His) ${ }_{6}$ RosR binds to an RosR-box sequence located upstream of $\operatorname{ros} R$. Deletion analysis of the rosR upstream region resulted in identification of two -35 to -10 promoter sequences, two conserved inverted palindromic pentamers that resemble the cAMP-CRP binding site of Escherichia coli, inverted repeats identified as a Ros $R$ binding site, and other regulatory sequence motifs. When assayed in $E$. coli, a transcriptional fusion of the cAMP-CRP binding site containing the ros $R$ upstream region and $l a c Z$ gene was moderately responsive to glucose. The sensitivity of the ros $R$ promoter to glucose was not observed in $E$. coli $\triangle c y a A$. A $\operatorname{ros} R$ frame-shift mutant of $R$. leguminosarum bv. trifolii formed dry, wrinkled colonies and induced nodules on clover, but did not fix nitrogen. In the ros $R$ mutant, transcription of $p s s A$-lac $Z$ fusion was decreased, indicating positive regulation of the $p s s A$ gene by RosR. Multiple copies of rosR in $R$. leguminosarum bv. trifolii 24.2 increased exopolysaccharide production.
\end{abstract}

Additional keywords: catabolic repression, zinc finger protein.

Rhizobium leguminosarum produces large amounts of acidic exopolysaccharide (EPS) that has been shown to be indispensable for nodule invasion and, therefore, for successful nitrogen-fixing symbioses with legumes that form an indeterminate type of nodules with persistent meristem, such as Medicago, Pisum, Trifolium, and Vicia spp. (Becker and Pühler 1998; Perret et al. 2000). EPS-deficient mutants of Rhizobium leguminosarum fail to nodulate their host plants (Borthakur et al. 1988) or induce formation of ineffective nodules (Rolfe et al. 1996, Skorupska et al. 1995; van Workum et al. 1997). The EPS of R. leguminosarum is a polymer of octasaccharide subunits, each composed of one galactose, five glucose, and two glucuronic acid residues, additionally decorated with acetyl,

Corresponding author: A. Skorupska; Telephone: +48 8153759 72, Fax: +48 8153759 59; E-mail: genet@ biotop.umcs.lublin.pl

Nucleotide and amino acid sequences are available in GenBank database under accession number AY683453 and AY683454. pyruvyl, and hydroxy-butanoyl modifications (Hollingsworth et al. 1988). EPS production requires the expression of several exo or pss genes. Most of them are dispersed throughout the genome, except for three major EPS clusters of chromosomal genes of R. leguminosarum bv. viciae (Young et al. 2006) and $R$. etli (González et al. 2006). The largest pss gene cluster includes the pss genes encoding specific glycosyl transferases, epimerases, and deacetylases involved in the biosynthesis of the EPS repeating unit, genes encoding proteins engaged in polymerization and transport of EPS, and other genes encoding enzymes that modify EPS (González et al. 2006; Skorupska et al. 2006). Most of these genes and their specific roles in EPS production have not been studied to date.

Unlike with Sinorhizobium meliloti, knowledge of regulation of pss gene expression in $R$. leguminosarum is only fragmentary. Previously, the psi and psr regulatory genes have been described in $R$. leguminosarum bv. phaseoli (now $R$. etli) (Lachford et al. 1991; Mimmack et al. 1994a,b). Even though a psiA mutant was not altered in its ability to produce EPS, it elicited empty nodules without infection threads and bacteria on Phaseolus spp. (Borthakur and Johnston 1987; Lachford et al. 1991). The increased copy number of psiA prevented the production of EPS in $R$. leguminosarum bvs. phaseoli and viciae and abolished nodulation ability of their respective hosts. The inhibitory effect of multiple copies of psiA on nodulation and EPS production could be overcome in the presence of additional copies of psr or pssA encoding the first glucosylIP-transferase (Lachford et al. 1991; Mimmack et al. 1994a,b). An exoR regulatory gene with extensive similarity to exoR of $S$. meliloti has been identified on the chromosome of R. leguminosarum bv. viciae (Reeve et al. 1997). An exoR mutant produced three times as much EPS as the wild-type strain, which suggested the role of this gene in negative regulation of EPS synthesis.

An $\operatorname{ros} R$ gene encoding a transcriptional regulatory protein has been identified in $R$. etli CE3 (Araujo et al. 1994, Bittinger et al. 1997). An ros $R$ deletion mutant formed mucoid, domed colonies, efficiently nodulated bean plants, and produced EPS that was identical to that produced by the wild-type strain. However, the mutant was significantly impaired with respect to nodulation competitiveness and nodule occupancy compared with the parental strain (Bittinger et al. 1997). R. etli RosR regulates more than 50 genes affecting the expression of many functionally diverse genes, as revealed by genome-wide genetic screening (Bittinger and Handelsman 2000).

RosR of $R$. etli shares significant identity with the Ros protein of Agrobacterium tumefaciens (Chou et al. 1998). Ros protein recognizes and binds the so-called ros-box, a 40-bp A:T-rich sequence located within the operators of virC and $\operatorname{virD}$ and 
upstream of the ipt gene. Ros negatively regulates virC and virD while positively affecting EPS production. Mutations in the ros gene result in derepression of $\operatorname{virC}$ and $\operatorname{virD}$ and the loss of succinoglycan production (Chou et al. 1998).

RosR of $R$. etli also displays high amino acid sequence similarity with MucR, which acts as a transcriptional repressor of galactoglucan (EPS II) production and an activator of succinoglycan (EPS I) production in S. meliloti 2011 (Becker et al. 1997; Keller et al. 1995). The $m u c R$ mutant produced EPS II, whereas only very small amounts of low molecular weight EPS I oligosaccharides were secreted (Keller et al. 1995; Zhan et al. 1989). MucR repressed exp genes encoding EPS II biosynthesis enzymes but had a weak or no effect on transcription of the exo genes that encode EPS I synthesis proteins (BertramDrogatz et al. 1998; Glazebrook and Walker 1989; Keller et al. 1995; Quester and Becker 2004). However, in S. meliloti EFB1, MucR is essential for galactoglucan production and $m u c R$ mutants are completely nonmucoid (Martin et al. 2000).

The C-terminal part of MucR/Ros proteins contains an amino acid sequence that reveals similarity to the $\mathrm{Cys}_{2} \mathrm{His}_{2}$-type zincfinger motif, which was found primarily in DNA-binding proteins of eukaryotic origin (Berg and Shi 1996; Cooley et al. 1991). Four conserved residues are ligands for a central zinc ion that stabilizes small globular domain (i.e., the finger domain) (Pabo and Sauer 1992). Eukaryotic transcription factors using this motif typically contain tandem arrays of such $\mathrm{C}_{2} \mathrm{H}_{2}$ zinc fingers that bind to neighboring sites on the DNA. Each finger has a conserved $\alpha \beta \beta$ structure and the amino acids on the surface of the $\alpha$-helix contact the bases in the major groove. MucR/Ros proteins contain only one zinc-finger motif. In Ros of $A$. tumefaciens, the peptide loop spacing of the zinc finger is 9 amino acids (aa) as opposed to the invariant 12 aa in the classical $\mathrm{C}_{2} \mathrm{H}_{2}$ motif (Chou et al. 1998).

In this study, we present the results of ros $R$ gene identification in $R$. leguminosarum bv. trifolii strains 24.2 and TA1. The ros $R$ gene undergoes a complex transcriptional control, as evidenced by mapping of several regulatory sites in the upstream region of $\operatorname{ros} R$ and deletion analysis of this region. The $\operatorname{ros} R$ gene is subject to negative autoregulation by its own protein product. Using an electrophoretic mobility shift assay (EMSA), we assayed binding of the purified (His) ${ }_{6}$ RosR protein to an RosR-box sequence identified in the ros $R$ upstream region. The $\operatorname{ros} R$ mutant formed dry, wrinkled colonies and elicited nodules on clover plants, but did not fix nitrogen.

\section{RESULTS}

Cloning of $\operatorname{ros} R$ gene and sequence analysis.

Using the genomic sequence of $R$. etli (Bittinger et al. 1997) as a guide in primer design, the ros $R$ homolog was isolated from $R$. leguminosarum bv. trifolii 24.2 and TA 1 strains by polymerase chain reaction (PCR) amplification. After amplification by PCR, rosR genes of 24.2 and TA1 strains were cloned into pUC19 to form the $\mathrm{pB} 31$ and $\mathrm{pB} 35$ plasmids, respectively, and the 1,174-bp insert of pB31 and 856-bp insert of pB35 were sequenced. In both cases, sequence analysis indicated the presence of a 432-bp-long open reading frame (ORF) with a putative ribosome binding site (AGGAGA) located 6 bp upstream of the potential ATG translation start codon (Fig. 1). Downstream of the TGA stop codon, a palindrome sequence of rho-independent transcription termination sites was found. The sequences of both $\operatorname{ros} R$ ORFs were identical; therefore, in further study, only the $\operatorname{ros} R$ gene of Rt24.2 strain was analyzed.

The predicted protein product of the ros $R$ coding region was composed of 143 aa $(15.7 \mathrm{kDa})$ and was highly similar to $R$. etli RosR (98\% identity at the protein level), S. meliloti MucR (80\% identity), A. tumefaciens Ros (80\% identity), A. radio- bacter RosAR (80\% identity), and Rhizobium sp. strain NGR234 MucR (75\% identity). Homologs of the rosR gene also have been found in other rhizobia (e.g., Mesorhizobium loti MAFF303099 [accession nos. BAB54066 and BAB52589] and Bradyrhizobium japonicum [accession number BAC48333]). Southern hybridization with the $\operatorname{ros} R$ gene as a probe showed one hybridization site, indicating a single ros $R$ locus in Rt24.2 and RtTA1 strains (data not shown).

As with other proteins of the Ros/MucR subfamily, a putative zinc-finger domain was found at the carboxy-terminal half of the RosR protein of Rt24.2. It was composed of 19 aa residues, including two conserved cysteines $(\mathrm{C})$ and two conserved histidines $(\mathrm{H})$ in a $\mathrm{C}-\mathrm{N}_{2}-\mathrm{C}-\mathrm{N}_{9}-\mathrm{H}-\mathrm{N}_{3}-\mathrm{H}$-type motif (Fig. 1). In this type of regulatory protein, one atom of $\mathrm{Zn}$ is tetrahedrally coordinated by the conserved $\mathrm{C}$ and $\mathrm{H}$ residues composing the finger, which interacts with short runs of guanine residues in DNA (Chou et al. 1998).

\section{Functional analysis of $\operatorname{ros} R$ upstream region.}

Computer analysis of the ros $R$ upstream region revealed the presence of several regulatory sequences, including the RosRbox (position -133 to -112 bp relative to the start codon) (Fig. 1). The RosR-box is a 22-bp-long sequence containing two nine-nucleotide inverted repeats separated by four $G$ and is the consensus sequence identified as the binding site for MucR/ Ros transcriptional regulators in rhizobia (Bertram-Drogatz et al. 1997; Keller et al. 1995). This sequence is identical to the Ros-box of R. leguminosarum bv. viciae (Young et al. 2006), almost identical to $R$. etli (Bittinger et al. 1997), and similar to the Ros-box of $A$. radiobacter (Brightwell et al. 1995) and $A$. tumefaciens (Cooley et al. 1991). The sequence of the MucRbox in S. meliloti (Keller et al. 1995) is most divergent (Fig. 2).

Upstream of the ros $R$ coding region, a putative promoter with a score of 0.95 (position -355 to $-278 \mathrm{bp}$ ) was identified. In the in silico predicted sequence, two putative promoters (P1 and P2), highly similar to the eubacterial sigma factor $\left(\sigma^{70}\right)$ binding site (Wösten 1998), were found: one -35 and -10 consensus sequence with an optimal spacing of 17 bp (5'-TTGGC $\mathrm{GN}_{17}$ TATTTG), and another -35 and -10 putative promoter with longer spacing between two hexamers (5'ATGCAAN ${ }_{20}$ TA CAAT) (Fig. 1). Apart from the promoters, at position -169 to -125 relative to the start codon, three repeats of a conserved T$\left(\mathrm{N}_{11}\right)$-A element were found. The element comprises a LysR motif present in many promoters regulated by LysR-type transcriptional regulators (Schell 1993), among them the NodD protein that positively controls the synthesis of the nodulation factor in rhizobial symbioses (Long 2001) and SyrM protein that belongs to the family of transcriptional activators of EPS I production in S. meliloti (Dusha et al. 1999). The third T- $\left(\mathrm{N}_{11}\right)$ A repeat partially overlaps the RosR-box.

To functionally analyze the putative $\operatorname{ros} R$ promoter, a set of plasmids with 5'-end (pEP0-pEP7) and 3'-end deletions (pEP8-pEP12) of the promoter region fused to a promoterless lac Z gene were constructed (Fig. 3). E. coli DH5 $\alpha$ cells were transformed with these plasmids, which subsequently were transferred conjugally to the wild-type Rt24.2 strain. $\beta$-galactosidase activities in DH5 $\alpha$ and Rt24.2 strains carrying plasmids with different lacZ fusions were assayed (Fig. 3). The pEP0 plasmid containing the longest promoter fragment revealed a significantly lower activity in DH5 $\alpha$ and slightly lower activity in Rt24.2 when compared with the next transcriptional fusion (pEP1). Starting from $-357 \mathrm{bp}(\mathrm{pEP} 2)$, the progressive 5 '-end deletions reduced the $\operatorname{ros} R$ expression level in both genetic backgrounds (Fig. 3). In E. coli, a nearly threefold reduction of LacZ activity was observed for the $-281 \mathrm{fu}-$ sion (plasmid pEP3) relatively to the -403 fusion ( $p E P 1$ ), and then a gradual decrease of activity up to the -219 fusion 
(pEP4). In Rt24.2, the reduction of LacZ activity for the -281 fusion (pEP3) was more drastic (approximately 6.5 times) and, for the -235 fusion (pEP3C), the LacZ activity was practically at the background level. Overall, deletion of the two putative promoters containing the -35 to -10 consensus elements (Fig. 1) resulted in complete reduction in $\beta$-galactosidase activity in both backgrounds.

When the $\operatorname{ros} R$ upstream sequence (Fig. 1) was further analyzed, two sequences highly similar to cAMP-CRP binding sites in E. coli (Ebright et al. 1989) were identified. Specific

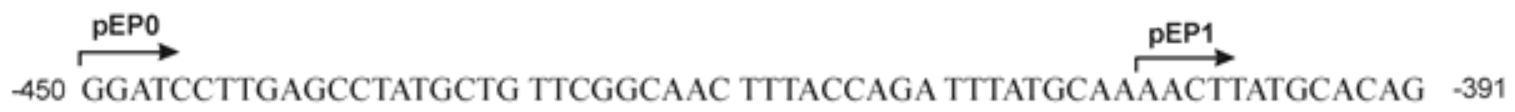
cAMP - CRP site 390 GAAGCTGTGAGTAAAGC TTGCTGGAGAGCCCCTCAA TTCTTCATCTGTCA TTTTTTCTCA

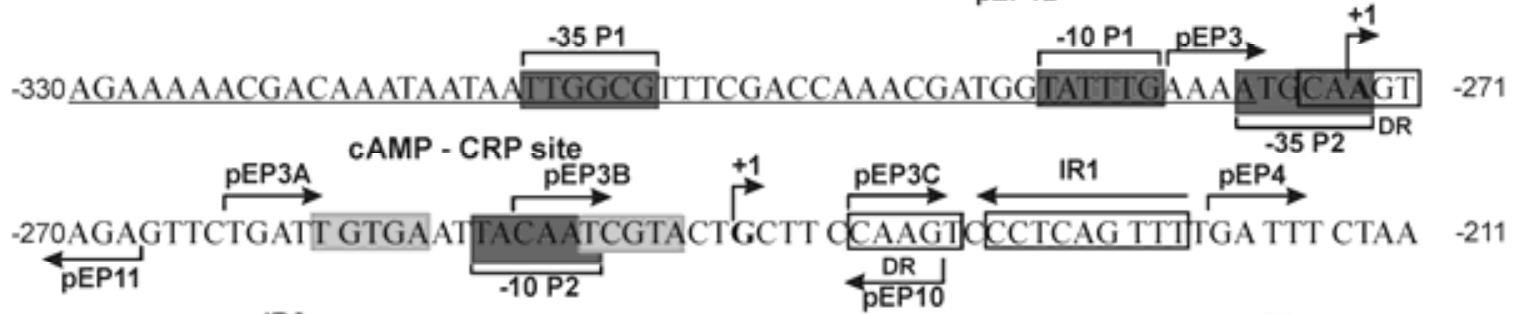

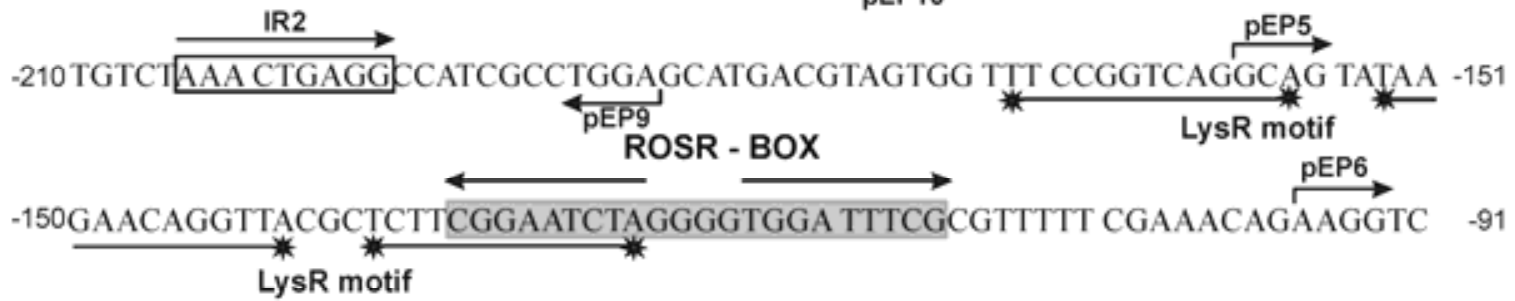
-90GATTCCTGCGC TTTTGCTG TTCGCTTCTACGAGGCGGGTC TTT GGCGTGTCAGTCAAAGG rbs +1 -30CCGTTTGAGCATGCTACCAGGAGAAAAATATGACGGATATAGCGACCGGCAATGCGCCG +30 +31GAGCTGCTTGTGGAACTGACAGCCGACATTGTCGCGGCCTATGTCAGCAACCACG TTGTA +90

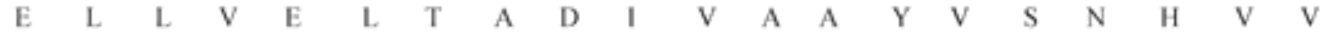
+91CCGGTCAGCGACCTGGCCAATCTGA TTTCCGACGTGCATTCGGCACTGAGTAACACGTCC +150 $\begin{array}{llllllllllllllllllllllll}P & V & S & D & L & A & N & L & I & S & D & V & H & S & A & L & S & N & T & S\end{array}$ +151GTACCGCAGCCTGCTGCGGCGATCGTdGAAAAGCAGAAGCCTGCAGTTTCTGTCCGCAAG +210

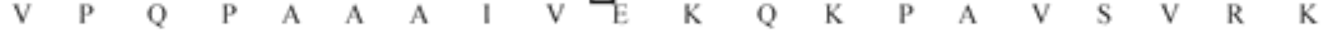
+211TCCGTACAGGACGAGCAGATCACATGTTJGGAATGCGGCGGCAACTTCAAGTCCCTCAAG +270 PRR1 $2 \mathrm{H} 2$ motif $\begin{array}{llllllllllllllllllllllllll}S & V & Q & D & E & Q & \text { I } & T & \mathrm{C} & \mathrm{L} & \mathrm{E} & \mathrm{C} & \mathrm{G} & \mathrm{G} & \mathrm{N} & \mathrm{F} & \mathrm{K} & \mathrm{S} & \mathrm{L} & \mathrm{K}\end{array}$ +271CGTCACTTGATGACGCATCACAGCCTCTCGCCGGAAGAATACCGCGAGAAGTGGGACCTG +330 $\begin{array}{llllllllllllllllllll}R & \text { H } & \mathrm{L} & \mathrm{M} & \mathrm{T} & \text { H } & \mathrm{H} & \mathrm{S} & \mathrm{L} & \mathrm{S} & \mathrm{P} & \mathrm{E} & \mathrm{E} & \mathrm{Y} & \mathrm{R} & \mathrm{E} & \mathrm{K} & \mathrm{W} & \mathrm{D} & \mathrm{L}\end{array}$ +331 CCGACCGATTACCCGATGGTAGCGCCCGCTTATGCCGAAGCGCGTTCGCGCCTGGC AAAG +390 $\begin{array}{lllllllllllllllllllll}\mathrm{P} & \mathrm{T} & \mathrm{D} & \mathrm{Y} & \mathrm{P} & \mathrm{M} & \mathrm{V} & \mathrm{A} & \mathrm{P} & \mathrm{A} & \mathrm{Y} & \mathrm{A} & \mathrm{E} & \mathrm{A} & \mathrm{R} & \mathrm{S} & \mathrm{R} & \mathrm{L} & \mathrm{A} & \mathrm{K}\end{array}$ +391GAGATGGGCCTCGGGCAGCGCCGCAAGCGCGGCCGCGGCTGAGCTTTTTCGAAAGCATCG +450

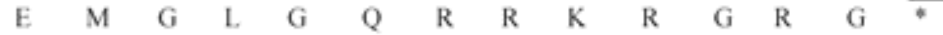
palindrome terminator +451 ACGACAAAAA GCCGGGTCTTGTGCCCGGCTTTTTT GTGCGCCTTTTCAAGGCGAGGAAAA +510 +511 TAATCTCGATGGAGCCAGTCAGGAACGTGCGAAACGGTTTTCCCAGGCAAAGCGCGAAGC+570 +571 GGT TTTGCCGGGAATCGGCTAAAGCTAAAGGTTGAAGCGATCCTGTGGTTCAATC AAAAG +630 +631 CTGAGCGGCGTTGGTATTCAGGCC TTCGCAGATGA TTCGGGCGGGCGCCAAGATAGTGTG +690 +691 AGCGACCCTGTCTTATGCTTTGCCGACAGGATCC

Fig. 1. Nucleotide sequence of 1,174-bp fragment containing rosR gene of Rhizobium leguminosarum bv. trifolii 24.2 with the upstream region. The deduced amino acid sequence of $\operatorname{ros} R$ is given in the single-letter code. The putative $\mathrm{C}_{2} \mathrm{H}_{2}$ motif in RosR protein, RosR-box, and cAMP-CRP binding sites are shaded in light gray. P1 and P2 -35 and -10 promoter sequences are marked by dark-gray shaded boxes. Transcription start sites are marked by an angled arrows. Putative promoters and palindromic terminator sequences are underlined. The ribosome binding site (rbs), translation start codon, and short, direct repeats (DR) are boxed. Long inverted repeats (IR1 and IR2) are overlined with arrows. LysR motifs are underlined and marked with stars. Overlined short arrows indicate location of primers used for polymerase chain reaction amplification of DNA fragments of the upstream ros $R$ region. Shaded box in +177 position of ros $R$ indicates deletion of $\mathrm{C}$ nucleotide resulting in a frame-shift mutation. 
binding sites for cAMP-CRP usually are located upstream of the promoters and are essential for transcriptional activation or repression. In the case of $\operatorname{ros} R$, the first imperfect inverted palindromic sequence, GC-TGTGA-N - -TTGCT-GG, was located upstream of the P1 promoter. The second cAMP-CRP binding site (i.e., AT-TGTGA-N - -TCGTA-CT) was found downstream of the P1 promoter and partially overlapped the -10 sequence of P2 (Fig. 1). It was identical (first pentamer) or highly similar (second pentamer) to the consensus sequence AANTGTGA-N - -TCACA-T, which is responsible for binding the CRP dimer in complex with cAMP in $E$. coli, resulting in the regulation of transcription (Kolb et al. 1993).

To assess the significance of both the cAMP-CRP sequences in $\operatorname{ros} R$ expression and their probable responsiveness to the carbon source, Rt24.2 strain derivatives carrying either i) plasmid pEP1 with the entire ros $R$ upstream sequence; ii) plasmid pEP3A lacking the entire $\mathrm{P} 1$ promoter and -35 hexamer of $\mathrm{P} 2$ but with the second, more conserved AN-TGTGA-N $-\mathrm{N}_{7^{-}}$ TCGTA-NT element; iii) plasmid pEP3B lacking the first pentamer of the second cAMP-CRP binding site; and iv) plasmid pEP3C with promoters and both cAMP-CRP binding sites deleted were examined. The strains were grown in M1 minimal medium supplemented with glycerol or glucose as sole carbon source and LacZ activity was measured (Fig. 4A). In strains carrying pEP1 and pEP3A plasmids, 40 and $32 \%$ reduction, respectively, in LacZ activity was observed in the presence of glucose compared with the activity in the presence of glycerol. In Rt24.2 derivative carrying pEP3C with both cAMP-CRP binding sites deleted (but also no promoters present), $\beta$-galactosidase activities were very low regardless of the carbon source (Fig. 4A). These results indicate that ros $R$ expression depends on the nature of the carbon source and is moderately affected by glucose. Both P1 and P2 promoters (Fig. 1) and at least the downstream putative cAMP-CRP binding site are essential for the transcriptional activation of $\operatorname{ros} R$ (Fig. 4A).

To further examine probable cAMP-CRP-mediated activation of $\operatorname{ros} R$ transcription, $\mathrm{pEP}$ constructs bearing the truncated promoter region fused to promoterless $l a c Z$ were transferred into E. coli cyaA mutant (VH1000cyaA) and a wild-type strain. E. coli strains harboring mutations of the cya gene (encoding adenylate cyclase) do not synthesize cAMP and fail to respond to catabolite repression by glucose. The $E$. coli derivatives were grown in the presence of glycerol or glucose and LacZ activities were measured (Fig. 4B and C). We observed that $\operatorname{ros} R$ expression was moderately reduced in the presence of glucose in an E. coli wild-type strain carrying pEP1 to pEP3A plasmids (Fig. 4B). The level of repression did not exceed $50 \%$ in the wild-type strain. In the case of pEP3B fusion lacking the first pentamer, the responsiveness of $\operatorname{ros} R$ transcription to glucose disappeared (Fig. 4B).

In the E. coli cyaA mutant carrying the same fusions as the ros $R$ upstream region, LacZ activity was practically invariable, regardless of the carbon source (Fig. 4C), indicating that cAMP is important for the responsiveness of $\operatorname{ros} R$ transcription to glucose. Moreover, the level of LacZ activity in the E. coli cyaA mutant bearing fusions pEP1 to pEP3A was lower (approximately 30 to $35 \%$ ) when grown in the presence of glycerol compared with the $E$. coli wild-type strain. This suggested positive regulation of $\operatorname{ros} R$ by cAMP-CRP.

Inverted repeats IR1 (CCTCAGTTT) and IR2 (AAACTGAGG) and two directly repeated short CAAGT sequences that might function as potential regulator binding sites also were detected in the rosR upstream region (Fig. 1).

The study of the $\operatorname{ros} R$ upstream region was supplemented by analysis of $\beta$-galactosidase activity in $E$. coli and Rt 24.2 strains bearing transcriptional fusions of the 3 '-end deleted promoter region with promoterless lacZ gene (Fig. 3). In both backgrounds, deletion of the -35 to -10 consensus of $P 1$ and P2 elements ( $p E P 12$ ) resulted in total lack of LacZ activity. The highest LacZ activity was observed in strain Rt 24.2 carrying pEP11 plasmid that contained the entire P1 promoter but was lacking the cAMP-CRP downstream element. LacZ activity of pEP11 was threefold higher compared with the pEP10 plasmid additionally bearing the P2 promoter and cAMP-CRP binding site. In pEP9, increase in LacZ activity (by a factor of 1.58) was observed in comparison with pEP10, indicating stimulatory effect of the IR1 and IR2 inverted repeats on rosR transcription. A low level of LacZ activity in pEP8 might be explained by the presence of the Ros-box bound by RosR protein, which would result in decreased $\operatorname{ros} R$ transcription. This indicated $\operatorname{ros} R$ autoregulation by its own protein product. It also is possible that the decrease in $\operatorname{ros} R$ transcription in $\mathrm{pEP} 8$ versus $\mathrm{pEP} 9$, in both genetic backgrounds, was caused by interaction of global regulatory LysR-type proteins with the LysR motif, synergistically with the effect of autoregulation (Fig. 3).

In conclusion, transcription of the $\operatorname{ros} R$ gene in strain Rt24.2 is directed from the P1 and P2 promoters. In the presence of glucose, transcriptional activity of $\operatorname{ros} R$ is reduced, indicating

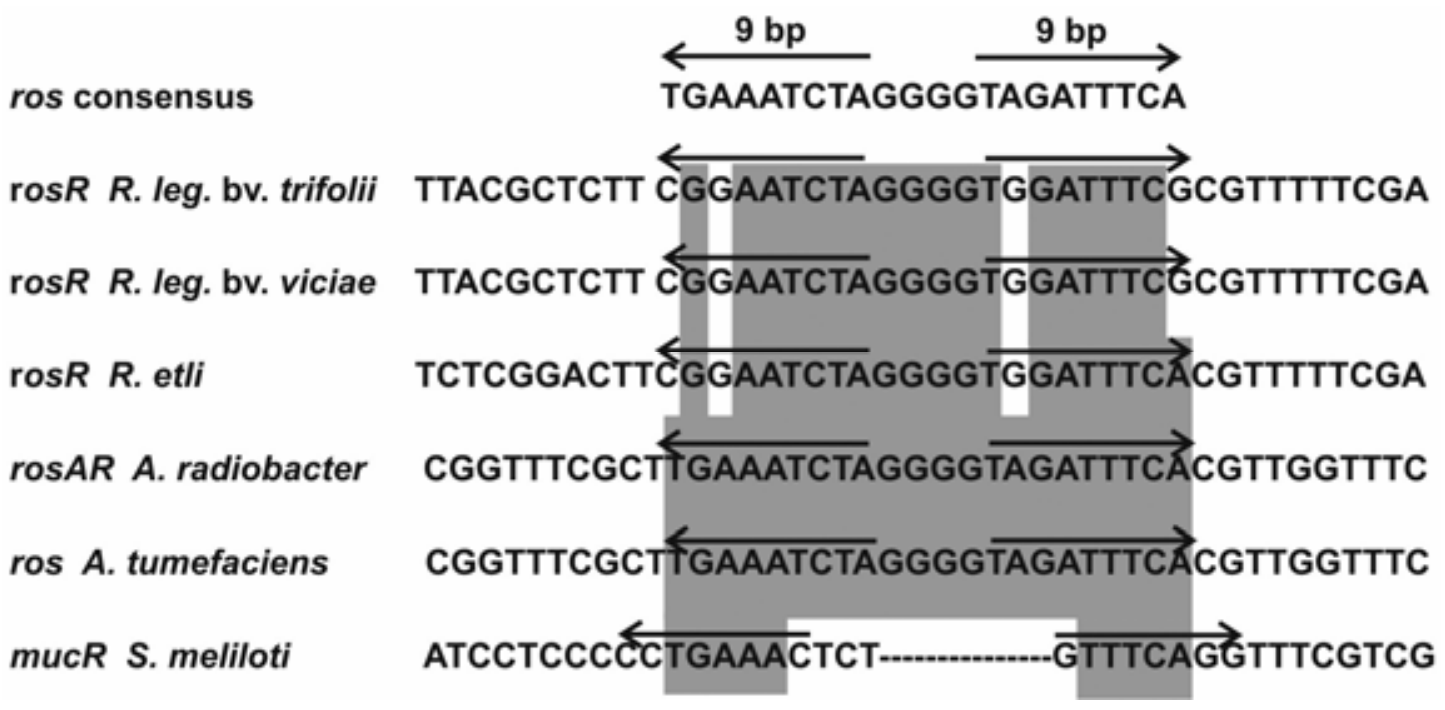

Fig. 2. Comparison of sequences that show similarity to Rhizobium leguminosarum bv. trifolii RosR binding site in the rosR upstream region. Nucleotides conserved in all sequences are shaded. Arrows indicate inverted repeats. 
$\operatorname{ros} R$ regulation by catabolic repression. Moreover, additional regulatory elements, first and foremost the RosR-box, modulate $\operatorname{ros} R$ transcription.

\section{Mapping of the start site of $\operatorname{ros} R$ transcription by primer extension analysis.}

To determine the transcription start site of $r o s R$, fluorescent primer extension analysis was carried out with a $5^{\prime}$-FAMlabeled oligonucleotide complementary to the $5^{\prime}$ end of the ros $R$ gene. Two primer extension products displaying similar abundance were detected (Fig. 5). One of them was 298 bp in length and the first nucleotide to be transcribed was an adenine (A) located -273 nucleotides (nt) upstream of the proposed ros $R$ translation start codon and $8 \mathrm{nt}$ downstream of -10 (TATTTG) sequence of the P1 promoter (Fig 1). The second primer extension product was $265 \mathrm{bp}$ in length and the first transcribed nucleotide was a guanine $(\mathrm{G})$ that was located -240 nt upstream of the rosR translation start codon and 6 nt downstream of the -10 (TACAAT) sequence of the predicted P2 promoter. Moderate LacZ activity in $\mathrm{pEP} 3, \mathrm{pEP} 3 \mathrm{~A}$, and $\mathrm{pEP} 3 \mathrm{~B}$ fusions and complete lack of LacZ activity in the pEP3C fusion with both promoters deleted confirms the transcriptional activity of the $\mathrm{P} 2$ promoter and the presence of the second -240-nt transcription start site (Figs. 1 and 3).

\section{Overproduction of RosR protein in E. coli.}

To overproduce Rt24.2 RosR as a recombinant N-terminally His-tagged protein, plasmid pQE450 was used (details below). A substantial portion of the (His) ${ }_{6}$ RosR protein was produced in an insoluble aggregated form. The soluble fraction of the protein was subjected to purification by Ni-NTA affinity chromatography. We have not observed the deleterious effect of (His) $)_{6}$ RosR overproduction on E. coli growth described in the case of MucR (Bertram-Drogatz et al. 1997) and Ros protein

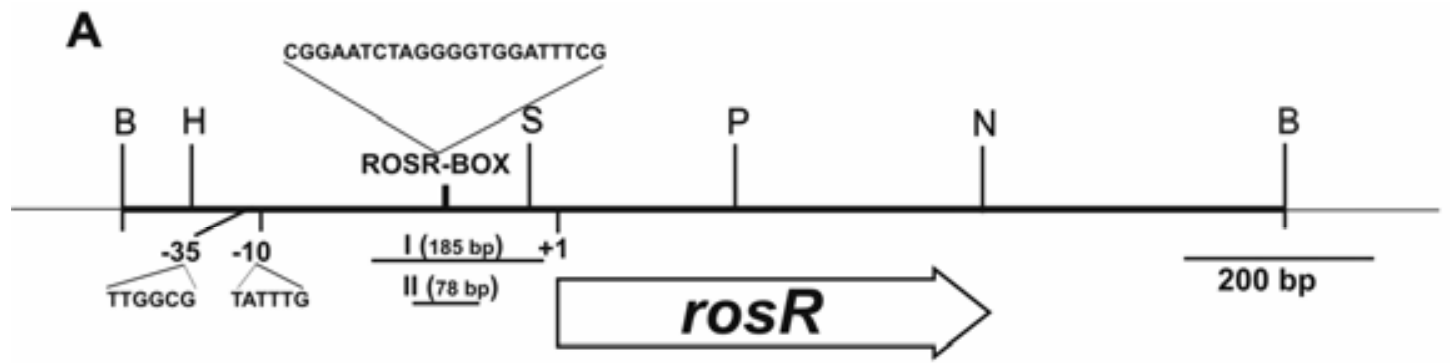

B

\begin{tabular}{lrcc} 
plasmid & $\begin{array}{c}\text { rosR promoter } \\
\text { region (nt) }\end{array}$ & $\begin{array}{c}\beta \text {-galactosidase } \\
\text { activity in } E \text {. coli } \\
\text { DH5 } \alpha \text { (Miller units) }\end{array}$ & $\begin{array}{c}\beta \text {-galactosidase } \\
\text { (Miller units) }\end{array}$ \\
\hline pEP0 & -450 to +1 & $2480 \pm 102$ & $2442 \pm 112$ \\
pEP1 & -403 to +1 & $6092 \pm 213$ & $2842 \pm 109$ \\
pEP 2 & -357 to +1 & $5917 \pm 186$ & $2703 \pm 132$ \\
pEP3 & -281 to +1 & $2270 \pm 136$ & $434 \pm 24$ \\
pEP3A & -263 to +1 & $1866 \pm 108$ & $443 \pm 33$ \\
pEP3B & -250 to +1 & $1248 \pm 82$ & $295 \pm 25$ \\
pEP3C & -235 to +1 & $160 \pm 39$ & $76 \pm 12$ \\
pEP4 & -219 to +1 & $157 \pm 33$ & $26 \pm 5$ \\
pEP5 & -159 to +1 & $109 \pm 29$ & $29 \pm 7$ \\
pEP 6 & -96 to +1 & $121 \pm 37$ & $22 \pm 7$ \\
pEP 7 & -41 to +1 & $112 \pm 22$ & $19 \pm 4$ \\
\hline pEP8 & -403 to -32 & $5735 \pm 179$ & $670 \pm 56$ \\
pEP9 & -403 to -185 & $6799 \pm 221$ & $1132 \pm 58$ \\
pEP10 & -403 to -232 & $4110 \pm 166$ & $716 \pm 28$ \\
pEP11 & -403 to -268 & $3455 \pm 148$ & $2176 \pm 99$ \\
pEP12 & -403 to -348 & $4 \pm 2$ & $2 \pm 2$ \\
\hline
\end{tabular}

Fig. 3. A, Physical and genetic map of Rt24.2 region encompassing rosR gene. Abbreviations: B, BamHI; P, PstI; H, HindIII; S, SphI; N, NotI. B, Transcriptional activity of ros $R$ putative promoter assayed in Escherichia coli DH5 $\alpha$ and Rt 24.2 strains carrying pMP220 plasmid with fragments of the ros $R$ upstream region fused with promoterless lac $Z$ gene. Lengths of polymerase chain reaction products in particular plasmids are shown as horizontal lines. E. coli strains were grown in Luria-Bertani medium; Rt24.2 strains were grown in 79CA medium with mannitol as carbon source. $\beta$-Galactosidase activities for the pEP0 to pEP12 plasmid fusions are given as the averages from at least three or four independent experiments. 
(Cooley et al. 1991). Purified (His) ${ }_{6}$ RosR was subjected to sodium dodecyl sulfate polyacrylamide gel electrophoresis (SDSPAGE) and a major band of approximately $18 \mathrm{kDa}$ was detected, in accordance with the deduced molecular weight of $15.7 \mathrm{kDa}$ for the $\operatorname{ros} R$ gene product and accounting for the presence of the $\mathrm{N}$-terminal $\mathrm{His}_{6}$-tag (Fig. 6A). The identity of (His) ${ }_{6}$ RosR was confirmed by Western blotting with anti-His $5^{-}$ tag antibodies (Fig. 6B). In the SDS-PAGE analysis of RosR protein, in addition to a major $18-\mathrm{kDa}$ band, a band of approximately $38 \mathrm{kDa}$ was detected.

Considering the possibility of self-association of RosR, in vitro chemical cross-linking with glutaraldehyde was performed.

A

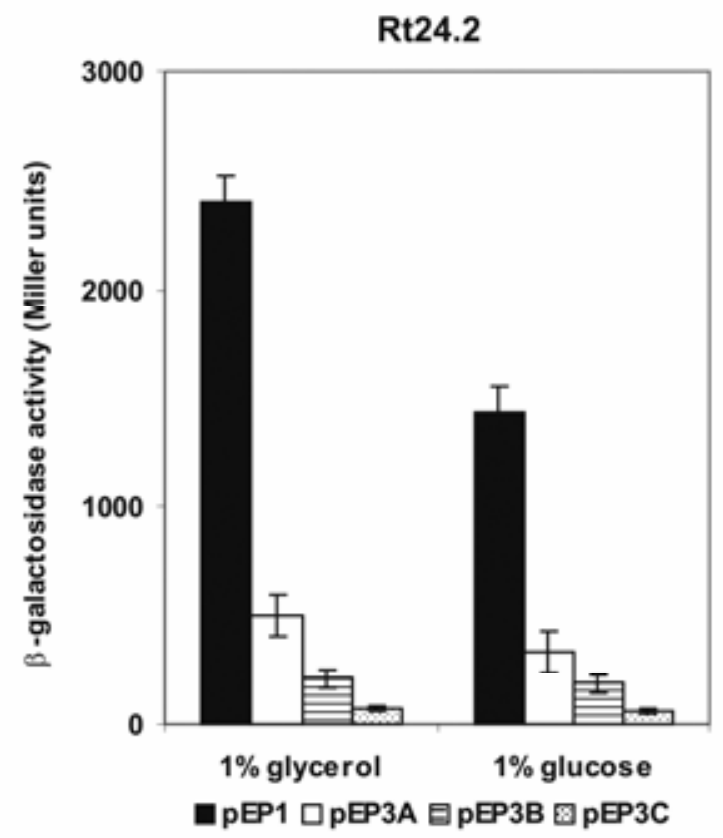

B

\section{E. coli wild type strain}

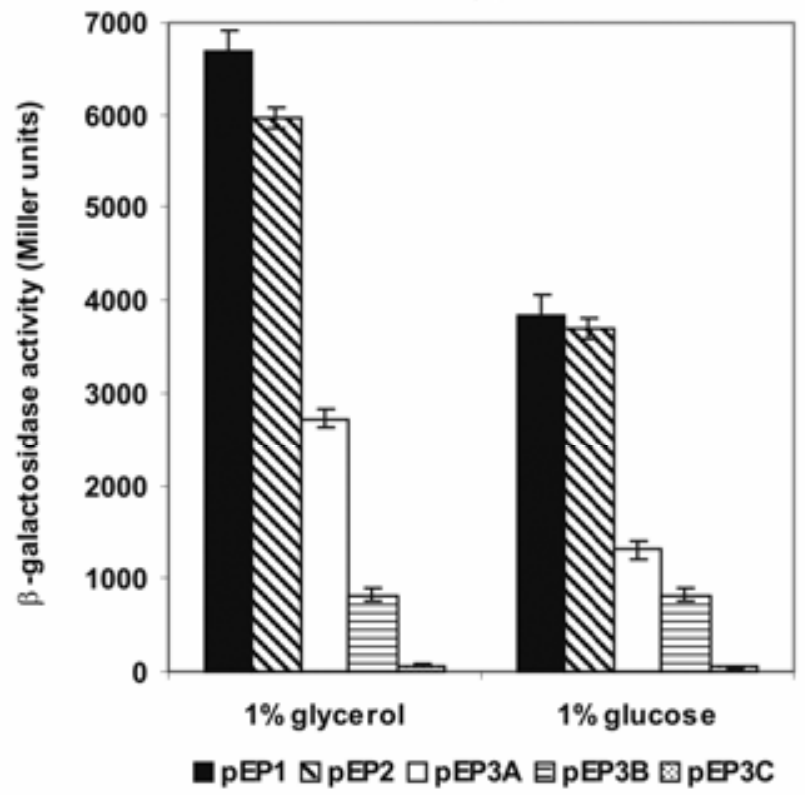

After treating RosR with even low $(0.01 \%)$ concentrations of glutaraldehyde, dimeric and trimeric forms were detected by Western blotting with anti-His ${ }_{5}$ antibodies (Fig. 6C). In the presence of an increasing concentration of glutaraldehyde, increased amounts of multimeric forms of RosR appeared at the expense of the monomeric one (Fig. 6C). This implies that RosR protein could function at least as a dimer.

\section{Binding of (His) ${ }_{6}$ Ros protein to the RosR-box.}

We performed EMSA to study DNA binding of purified (His) ${ }_{6}$ RosR fusion protein. For these experiments, we used a PCR-amplified 185-bp digoxigenin (DIG)-labeled DNA frag- 
ment I (encompassing the region from -193 to $-9 \mathrm{nt}$ ), matching the predicted RosR-box site in the $\operatorname{ros} R$ upstream region

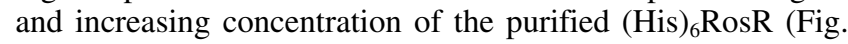
7A). The observed retardation was dependent on protein concentration with an increasing amount of protein, the molecular weight of the DNA-(His) ${ }_{6}$ RosR complex became visibly larger (Fig. 7A). However, (His) ${ }_{6}$ RosR at $2 \mathrm{ng} \mu \mathrm{l}^{-1}$ was sufficient to shift both the total amount of DNA fragment I and the shorter DNA 78-bp fragment II (region from -158 to $-81 \mathrm{nt}$ ) present in the samples (Fig. 7B).

To examine the DNA binding specificity of (His) ${ }_{6}$ RosR, electrophoretic mobility shift competition assays with unlabeled oligonucleotide competitor DNA fragments I to IV were carried out (Fig. 8). A DIG-labeled DNA RosR-box containing fragment I was used as a target for (His) ${ }_{6}$ RosR and oligonucleotides I to IV as competitors in all reactions (Fig. 8A through D). DNA fragment I (185 bp) had to be in a 100-fold excess over labeled DNA in order to effect full competition, as may be seen by the absence of a visibly shifted band (Fig. 8A). The shorter fragment II (78 bp), comprising nucleotides -158 to -81 upstream of $\operatorname{ros} R$, was more effective in competition, because a 10-fold excess of DNA was sufficient for full competition (Fig. 8B). This probably might be explained by a higher diffusion rate of smaller fragments (Bertram-Drogatz et al. 1997). When DNA fragment III (160 bp) containing the Ros-box of A. tumefaciens was used as a competitor, it had to be in a 500-fold excess to sufficiently compete with DNA fragment I (Fig. 8C). Furthermore, DNA fragment IV (158 bp) containing the MucR-box even in 500-fold excess did not compete with labeled DNA (Fig. 8D). These data indicated high specificity of (His) ${ }_{6}$ RosR binding to the RosR-box in fragment II and lower specificity binding with fragment I. In competition assays with heterologous fragments III and IV, the binding was less specific.

\section{ros $R$ mutant and complementation analysis.}

To assess the function of RosR in R. leguminosarum bv. trifolii and its possible engagement in EPS biosynthesis regulation, as was done in the case of Ros/MucR proteins (BertramDrogatz et al. 1997; Cooley et. al. 1991; Keller et al. 1995), we have attempted to construct a $\operatorname{ros} R$ deletion mutant lacking the entire ORF. A construct in which the $\operatorname{ros} R$ gene was replaced by a spectinomycin cassette was obtained and introduced into the Rt24.2 wild-type strain in order to generate the null mutation. However, we were not able to select desirable transconjugants. Thus, we subcloned the rosR ORF from $\mathrm{pB} 31$ plasmid into suicide vector $\mathrm{pK} 19 \mathrm{mobGII}$ and the construct was used to transform E. coli S17-1 (discussed below). Verification of insert correctness of several recombinant plasmids by sequence analyses revealed that the rosR ORF of one of the plasmids, named pEPB12, had one nucleotide deletion $(\Delta \mathrm{C}$ in position $+177 \mathrm{nt}$ ) (Fig. 1). The deletion caused a frame shift mutation starting with the 60th amino acid residue and created a nonsense codon (TGA) in position +277 , which resulted in synthesis of a shorter putative RosR protein (92 instead of 143 aa). In addi- tion, we identified nucleotide substitutions resulting in L38P and D41E mutations of RosR. We used pEPB12 plasmid to construct the ros $R$ mutant by homologous recombination. pEPB12 was transferred from E. coli $\mathrm{S} 17-1$ to $R$. leguminosarum bv. trifolii 24.2 by conjugation and the clone, named Rt2440, with altered, dry, wrinkled colony morphology was isolated (Fig. 9A). The Rt2440 mutant strain induced nodules on clover but inoculated plants appeared yellowish, indicating inefficient symbiosis (Table 1). The amount of EPS produced by the Rt2440 mutant was $35 \%$ of wild-type strain Rt24.2. Symbiotic and EPS deficiency defects in the Rt2440 mutant were complemented by the wild-type ros $R$ allele (Table 1 ).

The function of Rt24.2 RosR also was studied by complementation of ros $R$ mutation in the closely related species $R$. etli CE3 3 ros $R$. The mutant forms very characteristic domed colonies on agar plates because of their highly hydrophobic surface, whereas the parental strain CE3 produces flat colonies with hydrophilic cell surface (Bittinger et al. 1997). To study the possibility of restoring wild-type morphology of the CE3 $4 \operatorname{ros} R$ mutant by ros $R$ of Rt24.2, plasmid pRC24 was introduced by conjugation. As a result, flat, mucoid wild-type colony morphology was restored in mutant CE3 $\Delta$ ros $R$ (Fig. 9B). EPS production was measured in the exconjugants CE3 3 rosR(pRC24) and compared with the level of EPS produced by mutant CE3 $\Delta$ ros $R$ and wild-type CE3 strains. Nearly two times more EPS was produced in CE3 $\Delta \operatorname{ros} R$ (pRC24) (glucose equivalents at $1.55 \mu \mathrm{g} / \mu \mathrm{g}$ of protein) than in wild-type strain CE3 (glucose at $0.93 \mu \mathrm{g} / \mu \mathrm{g}$ of protein) and three times more than in the mutant strain CE3 $\Delta \operatorname{ros} R$ (glucose equivalents at $0.54 \mu \mathrm{g} / \mu \mathrm{g}$ of protein).

Complementation tests in which plasmid pRC24 was conjugally transferred into the $m u c R$ mutant of $S$. meliloti (Keller et

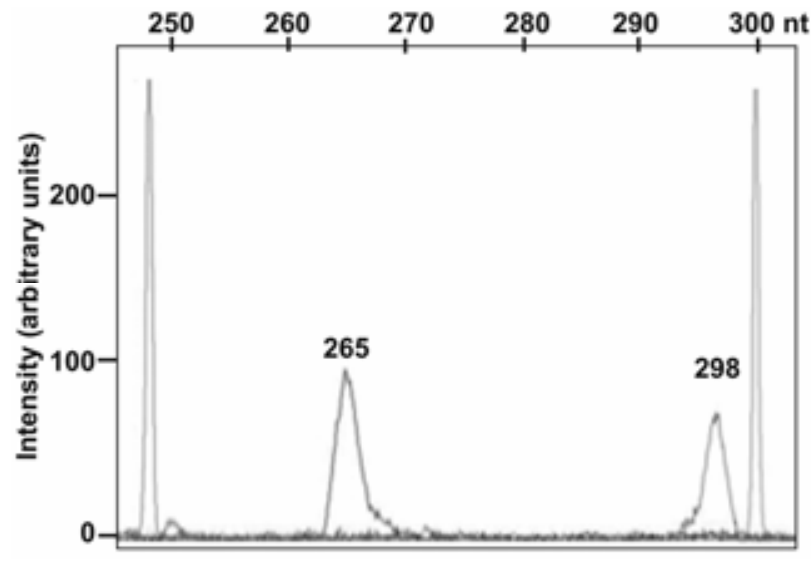

Fig. 5. Primer extension analysis of $\operatorname{ros} R$ promoter. Fluorogram obtained from a primer extension assay with $20 \mu \mathrm{g}$ of total RNA and a FAM-labeled primer corresponding to position +25 to -2 bp of the rosR sequence. Length of cDNA primer extension products is given above the peaks. Two high peaks are the GeneScan-500 ROX internal lane standards with the size of 247 and 300 bases.

Table 1. Complementation of the Rhizobium leguminosarum bv. trifolii 2440 ros $R$ mutant by pRC24 carrying the ros $R$ gene ${ }^{\mathrm{a}}$

\begin{tabular}{|c|c|c|c|c|c|c|c|}
\hline \multirow[b]{2}{*}{ Strain, plasmid } & \multicolumn{5}{|c|}{ Nodule no. per plant (days after infection) } & \multirow[b]{2}{*}{ Shoot wt $\left(\mathrm{mg} \mathrm{plant}^{-1}\right)^{\mathbf{b}}$} & \multirow[b]{2}{*}{$\operatorname{EPS}\left(\mathrm{mg} \mathrm{mg}^{-1}\right)^{\mathrm{c}}$} \\
\hline & 5 & 15 & 21 & 30 & 35 & & \\
\hline Rt2440 & 0.13 & 2.5 & 4.2 & 7.1 & 7.7 & $45.8 \pm 11.2(62.7 \%)$ & $0.34 \pm 0.03(35 \%)$ \\
\hline Rt2440(pRC24) & 0.35 & 4.6 & 7.9 & 12.4 & 13.7 & $66.5 \pm 12.8(91 \%)$ & $1.15 \pm 0.08(121 \%)$ \\
\hline Rt 24.2 & 0.5 & 6.9 & 9.5 & 15.3 & 16.8 & $73.0 \pm 14(100 \%)$ & $0.95 \pm 0.07(100 \%)$ \\
\hline Uninoculated clover & $\ldots$ & $\ldots$ & $\ldots$ & $\ldots$ & $\ldots$ & $30.2 \pm 7.5(41.4 \%)$ & $\ldots$ \\
\hline
\end{tabular}

${ }^{a}$ Given values ( \pm standard deviation) are averages of two independent experiments with 30 plants for each treatment.

${ }^{\mathrm{b}}$ Shoot fresh weight.

${ }^{\mathrm{c}}$ Exopolysaccharide (EPS) production (Glc equivalents in $\mathrm{mg} / \mathrm{mg}^{-1}$ of protein). 
al. 1995) or ros mutant of A. tumefaciens (Cooley et al. 1991) did not yield positive results, signifying that the $\operatorname{ros} R$ gene of $R$. leguminosarum bv. trifolii 24.2 did not complement $m u c R$ or ros mutations in the respective mutant strains.

To assess the effect of multiple copies of $\operatorname{ros} R$ on EPS production and symbiosis with clover, plasmid pBR24 was conjugally transferred into strain Rt24.2. The exconjugants Rt24.2 (pBR24) produced increased amount of EPS (128\% of the wild-type Rt24.2 strain) and induced more nodules on clover (data not shown). These results suggested that RosR positively regulates EPS synthesis in $R$. leguminosarum bv. trifolii 24.2.

\section{Regulatory function of RosR.}

To study regulation of $\operatorname{ros} R$ transcription, we introduced pEP1 fusion, where expression of a promoterless lac $Z$ gene was under the control of the entire upstream region of rosR into wild-type Rt24.2 and Rt2440 mutant strains (Table 2). Activity of $\beta$-galactosidase was twofold higher in the Rt 2440 ros $R$ mutant than in the wild-type strain, which indicated autoregulation of $\operatorname{ros} R$. In the wild-type background, LacZ activity was decreased in the presence of both the pEP1 fusion and pBR24 with the rosR gene, confirming the repressive effect of RosR on its own transcription.

The effect of RosR on transcription of the pssA gene encoding the first IP-glucosyltransferase in the pathway of $R$. leguminosarum EPS repeating unit synthesis (Pollock et al. 1998) was examined. In the upstream region of the pssA gene of

Table 2. Analysis of regulatory function of the $\operatorname{ros} R$ gene

\begin{tabular}{lcc}
\hline Strain and plasmids & $\begin{array}{c}\beta \text {-Galactosidase activity } \\
\text { (Miller units) }^{\mathbf{a}}\end{array}$ & Fold \\
\hline Rt24.2 (pEP1) & $2,896 \pm 113$ & 1 \\
Rt2440 (pEP1) & $5,854 \pm 241$ & 2 \\
Rt24.2 (pEP1, pBR24) & $1,917 \pm 102$ & 0.66 \\
Rt24.2 (pSF2) & $273 \pm 20$ & 1 \\
Rt2440 (pSF2) & $164 \pm 14$ & 0.6 \\
Rt24.2 (pSF2, pBR24) & $408 \pm 32$ & 1.49 \\
\hline
\end{tabular}

${ }^{a}$ Given values ( \pm standard deviation) are averages of three independent experiments.
A

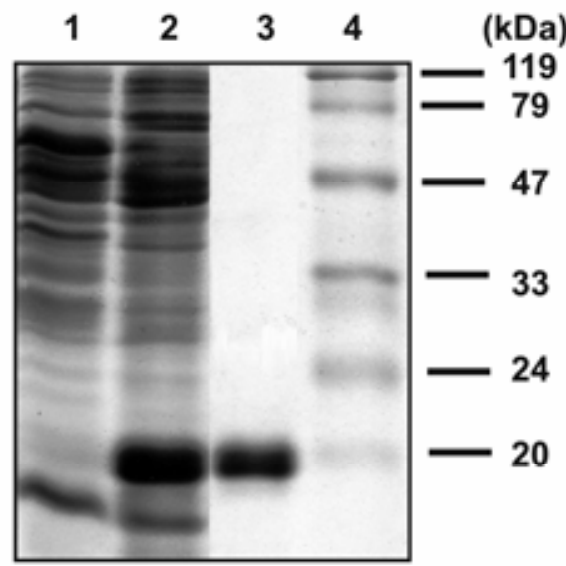

B

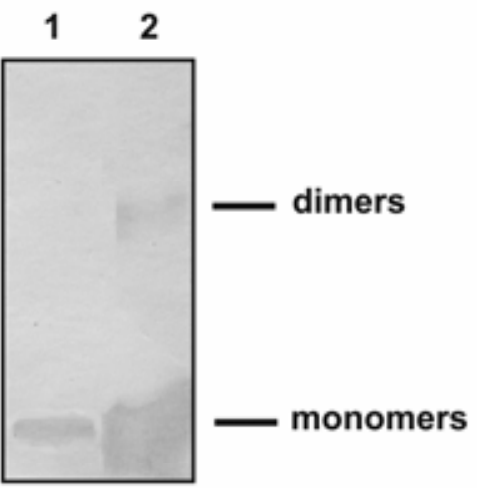

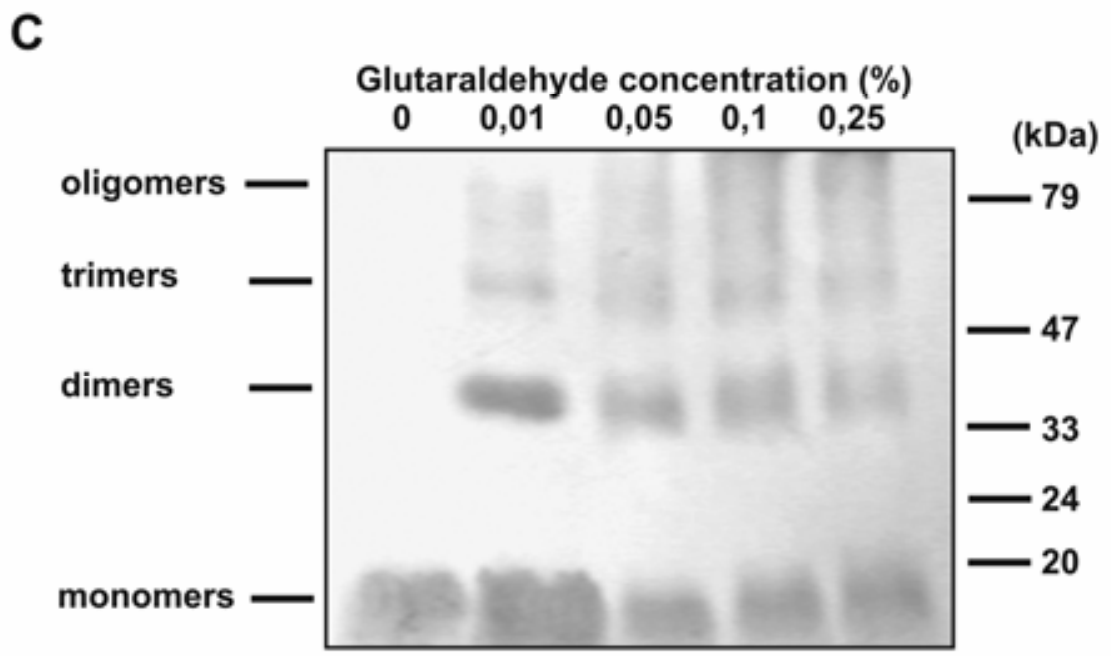

Fig. 6. A, Purification of (His) ${ }_{6}$ RosR protein overproduced in Escherichia coli M15 harboring pQE450. Soluble proteins were separated by $12 \%$ sodium dodecyl sulfate polyacrylamide gel electrophoresis and stained with Coomassie brilliant blue. Lane 1, proteins from uninduced E. coli M15(pQE450) cells; lane 2, proteins after induction with $1 \mathrm{mM}$ IPTG; lane 3, purified (His) ${ }_{6}$ RosR protein eluted from Ni-NTA agarose, and lane 4, proteins molecular mass

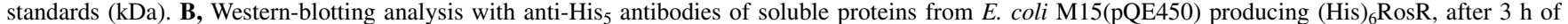
induction with $1 \mathrm{mM}$ IPTG, lane 2, (His) ${ }_{6}$ RosR; and lane 1, purified (His) ${ }_{6}$ RosR. Positions monomers and dimers are indicated. C, Western-blotting analysis of purified (His) ${ }_{6}$ RosR protein with anti-His ${ }_{5}$ antibodies after treatment with increasing concentration of glutaraldehyde. Positions of monomers, dimers, trimers, and multimers are indicated. Molecular weight standards $(\mathrm{kDa})$ are indicated at the right. 
strain Rt24.2, an RosR-binding site putatively able to bind RosR was identified earlier (Janczarek and Skorupska 2004). Plasmid pSF2 containing a transcriptional fusion of the pssA upstream region with promoterless lac $Z$ gene was introduced into Rt24.2 and the Rt2440 rosR mutant. Absence of RosR activity in the mutant background resulted in a decrease of $\beta$ galactosidase activity (by a factor of 0.6), indicating an apparent positive effect of the $\operatorname{ros} R$ gene product on $p s s A$ transcription (Table 2). In the wild-type strain, in the presence of additional copies of $\operatorname{ros} R$ (plasmid pBR24), the level of pssA transcription was increased by a factor of 1.5 . Overall, $\operatorname{ros} R$ gene transcription was negatively autoregulated by RosR but the pssA gene encoding a key enzyme in EPS synthesis was positively regulated.

\section{DISCUSSION}

In the present study, the $R$. leguminosarum bv. trifolii 24.2 $\operatorname{ros} R$ gene was identified and overexpressed in $E$. coli as an $\mathrm{N}$ terminally $\mathrm{His}_{6}$-tagged fusion protein containing a $\mathrm{C}$-terminal conserved zinc-finger DNA-binding domain, as predicted in silico. The Ros/MucR subfamily of $\mathrm{C}_{2} \mathrm{H}_{2}$ zinc-finger proteins comprises global positive or negative regulators of transcription of genes involved in diverse functions in prokaryotes, one being the regulation of EPS synthesis in S. meliloti, A. tumefaciens, and $A$. radiobacter (Bittinger and Handelsman 2000, Chou et al. 1998; D'Souza-Ault et al. 1993, Rüberg et al. 1999). RosR of Rt24.2 is very conservative in its amino acid composition and the $\mathrm{C}_{2} \mathrm{H}_{2}$ zinc-finger motif. Transcriptional regulators that bind DNA usually act as dimers, and the presence of RosR of Rt24.2 as dimeric and multimeric structures was demonstrated in this study. Binding of the (His) ${ }_{6}$ RosR protein to the RosR-box was evidenced by retardation of 185 and 78-bp DNA fragments, both matching a 22-bp-long consensus sequence. The specificity of (His) ${ }_{6}$ RosR binding to fragments I and II was demonstrated by competition experiments. Fragment III containing the Ros-box of A. tumefaciens (Cooley et al. 1991; D'Souza-Ault et al. 1993) competed with low affinity, because a 500-fold excess of the competitor over fragment I was needed to achieve competition. The RosR-box sequence of Rt24.2 is identical to the RosR-box of R. legumi- nosarum bv. viciae, almost identical to the Ros-box of $R$. etli, and similar to the RosR-box of $A$. radiobacter and $A$. tumefaciens. The sequence of the MucR-box of $S$. meliloti is most divergent (Bertram-Drogatz et al. 1998; Keller et al. 1995) and MucR protein did not bind the Ros-box of A. tumefaciens, indicating a high-specificity interaction between MucR and its DNA target (Bertram-Drogatz et al. 1997).

In addition to the RosR binding sequence, several regulatory sequences have been mapped in the upstream region of Rt24.2 $\operatorname{ros} R$, indicating a complex transcriptional control of $\operatorname{ros} R$. A deletion analysis of the region upstream of $\operatorname{ros} R$ revealed a dependence of ros $R$ transcription on $\mathrm{P} 1$ and $\mathrm{P} 2$ promoters containing conserved $\sigma^{70}$-dependent -35 or -10 motifs. Primer extension mapping detected two transcription start sites. Based on the primer extension data and sequence analysis of the upstream promoter region, separate -35 and -10 consensus sequences could be assigned for each transcript. Based on analyses of the LacZ activities, one could conclude that the P1 promoter is stronger than the $\mathrm{P} 2$ promoter, but an insignificant difference in the amount of both cDNA fragments in the primer extension assay indicated a comparable level of the two transcripts. Further experiments are needed to elucidate the activity of these promoters under different conditions.

These promoter sequences also were active in E. coli strains, where we observed a two-fold higher LacZ activity of plasmid fusions compared with native Rt24.2 background, indirectly indicating autoregulation of the $\operatorname{ros} R$ gene. Negative autoregulation of the $\operatorname{ros} R$ transcription also was evidenced by increased ros $R$ expression in the absence of RosR in the Rt2440 mutant background. The ros $R$ expression was visibly depressed in the presence of additional copies of $\operatorname{ros} R$. Similarly, negative autoregulation of the ros gene in A. tumefaciens (Cooley et al. 1991) and mucR in S. meliloti (Keller et al. 1995) has been reported.

Plasmid fusions carrying 5 '- and $3^{\prime}$-end deletion fragments of the $\operatorname{ros} R$ upstream region with the reporter $l a c Z$ gene allowed us to examine the significance of cAMP-CRP binding sites in activation of $\operatorname{ros} R$ transcription. The $5^{\prime}$-end deletions of both promoters reduced transcription to the background level in both Rt24.2 and E. coli. Transcription assays of rosR in the E. coli mutant lacking $c y a A$, the gene encoding adenylate cyclase, showed that, in the absence of cAMP, the ros $R$ promoter ceased
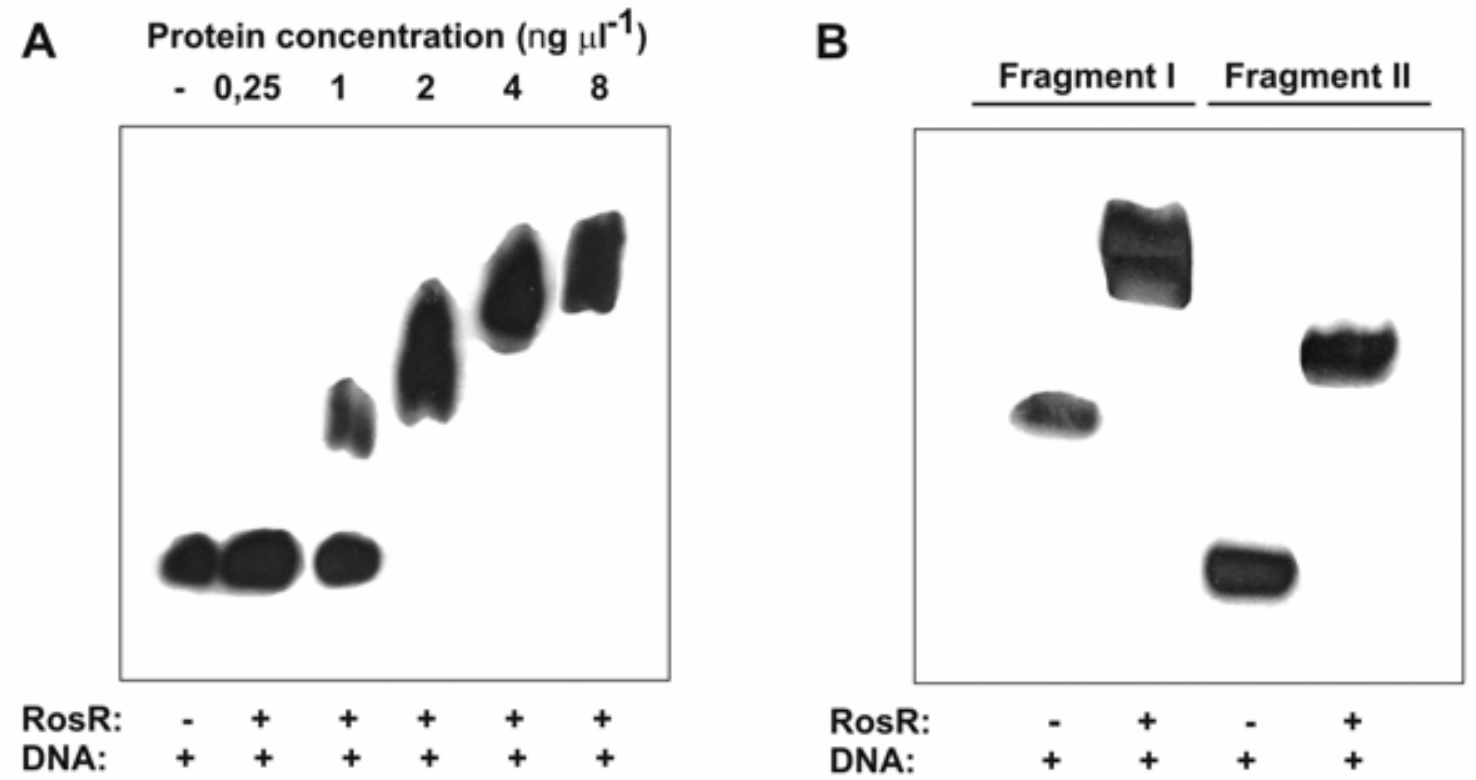

Fig. 7. A, Electrophoretic mobility shift analysis with purified (His) $)_{6}$ RosR of increasing concentration. Digoxigenin-labeled DNA A, fragment I and B, fragments I and II matching a consensus RosR-box were added to all reactions to give a final concentration of $0.1 \mathrm{ng}^{\mathrm{l}^{-1}}$. Protein concentration in $\mathbf{B}$ was $2 \mathrm{ng} \mu \mathrm{l}^{-1}$. 
to be responsive to glucose. We conclude that cAMP-activated CRP protein is able to recognize specific DNA sites and positively regulates $\operatorname{ros} R$ expression. Unexpectedly, a 3'-end deletion construct containing both the promoters and cAMP-CRP binding site (pEP10 fusion) showed lower transcription than pEP11 fusion. This could be explained by the fact that bacteria were cultured in complete medium and, under these conditions, the cAMP-CRP complex probably was not formed. This effect was not observed in E. coli background where LacZ activity increased with increasing length of the upstream region.

Computer search for cAMP-CRP binding sites in the rosR promoter region of $R$. etli revealed a sequence identical to the one found in R. leguminosarum bv. trifolii 24.2, located at the

\section{Competitor $\quad-2 \times 10 \times 50 \times 100 \times 500 x$}

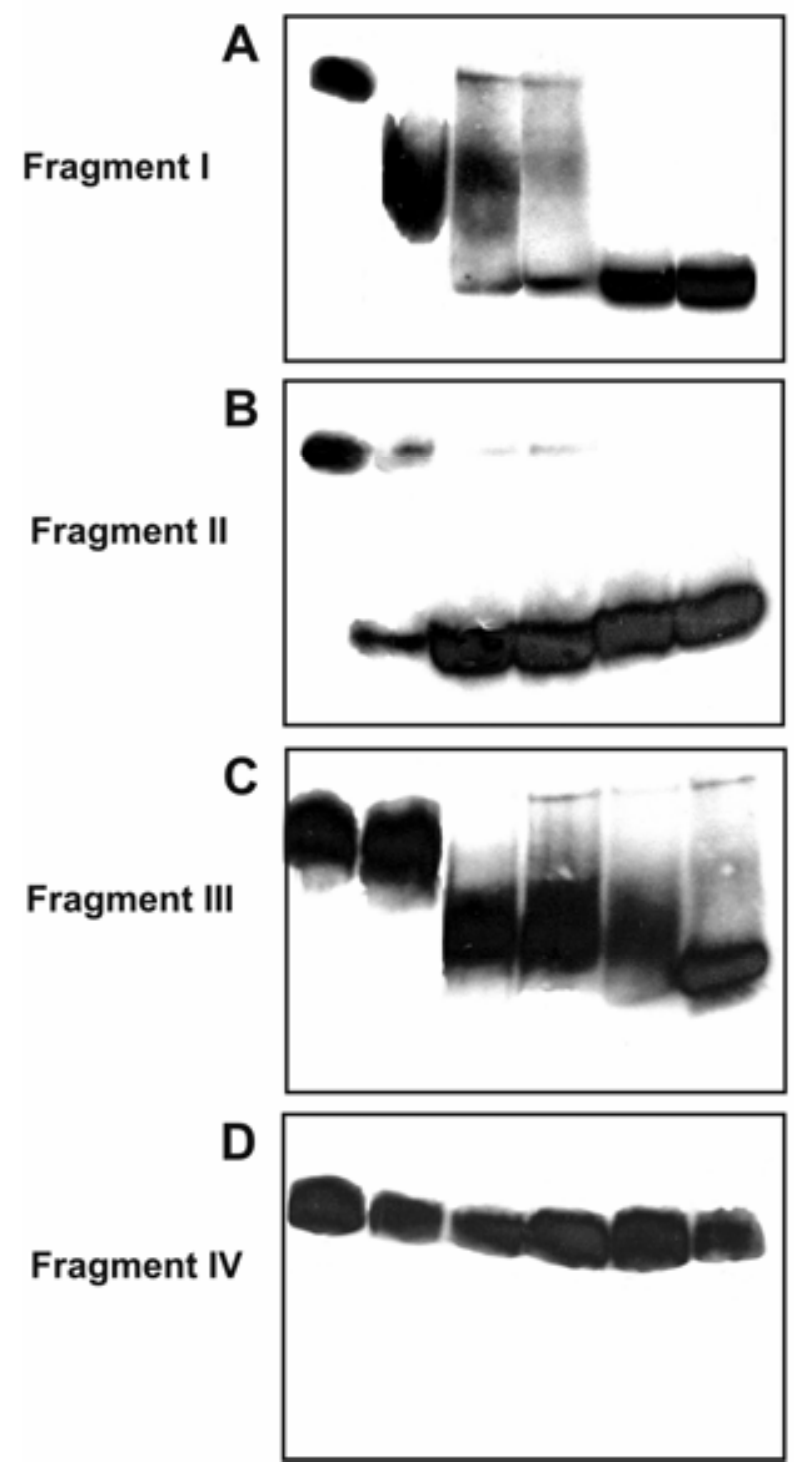

Fig. 8. Binding specificity of purified (His) ${ }_{6}$ RosR protein with RosR-box studied by electrophoretic mobility shift assays. Digoxigenin (DIG)labeled DNA fragment I was added to the reactions to give a final concentration of $0.1 \mathrm{ng}^{-1} \mathrm{l}^{-1}$. Protein was added in a final concentration $2 \mathrm{ng}$ $\mu^{-1}$. Unlabeled competitor oligonucleotides (I to IV) were added in increasing amounts from 2- to 500-fold excess over the DIG-labeled DNA fragment I. A, DNA fragment I (185 bp) and B, DNA fragment II (78 bp) contain the RosR-box of Rhizobium leguminosarum bv. trifolii, C, DNA fragment III (160 bp) contains the Ros-box of Agrobacterium tumefaciens, and D, DNA fragment IV (158 bp) matches the MucR-box of Sinorhizobium meliloti. same distance (-244 nt) from the RosR start codon. The cAMPCRP binding site located upstream of P1 promoter also was nearly identical (two substitutions). In the cases of $S$. meliloti and $A$. radiobacter, conservative cAMP-CRP binding sites ( $\mathrm{Sm}$ : GT-TGTGA-N ${ }_{6}$-TCCGT-TG; Ar: CG-TGTCA-N 6 -TCACT-AA) downstream of the main promoter were found to be highly similar to $E$. coli consensus sequence AAN-TGTGA-N - TCA CA-T. The cAMP-CRP binding sites located upstream from the main promoter were much more divergent in comparison to consensus.

Formation of the cAMP-CRP complex in E. coli and related bacteria is a prerequisite to transcriptional activation of catabolic genes. Specific binding sites for the complex usually are located upstream of these promoters; however, CRP-dependent promoters (class III promoters) regulated by multiple sites or by CRP in combination with one or more additional protein factors also have been described (Harman 2001). Although the mechanism of cAMP-CRP complex function in rhizobia remains unknown, multiple cya genes encoding adenyl cyclases have been identified and some of them have been cloned and characterized (Sharypowa et al. 1999; Tellez-Sosa et al. 2002). In addition, a hypothetical ORF, Crp1 (accession number DQ384109), with homology to the effector domain of the CAP family of transcription factors, was identified recently in the genome of $R$. leguminosarum bv. trifolii TA1.

Because RosR is considered to be an activator of acidic EPS biosynthesis in R. leguminosarum bv. trifolii and its intracellular concentration might be regulated by glucose, a possibility exists of a regulatory linkage between carbon metabolism and EPS production. There are several lines of evidence indicating the dependence of EPS production in R. leguminosarum bv. trifolii on the identity of the carbon source (Zevenhuizen 1986). Carbon source-dependent regulation of expression of pss genes in $R$. leguminosarum bv. trifolii could be directed by the ros $R$ gene product that might function as a positive transcriptional regulator of the pssA gene. Possible regulatory effect of RosR protein on other pss genes remains to be elucidated.

In addition to the regulatory sites discussed above, several other elements putatively involved in $\operatorname{ros} R$ regulation were identified upstream of $\operatorname{ros} R$, among them a three-times-repeated LysR-binding motif. LysR-type transcriptional regulators containing helix-turn-helix DNA-binding domain, such as SyrM protein, are involved in regulation of EPS production in $S$. meliloti (Barnett and Long 1997, Dusha et al. 1999). Under nitrogen limitation, NtrC and SyrM proteins act as positive regulators of succinoglycan production. The significance of LysR elements in $\operatorname{ros} R$ expression and of other, long and short inverted repeats remains to be elucidated. In conclusion, expression of the ros $R$ gene encoding a transcriptional regulator requires complex control on the transcriptional level, possibly involving interaction of different proteins.

Numerous attempts to mutate the ros $R$ gene in strain Rt24.2 eventually resulted in the construction of the Rt2440 mutant, which formed colonies with characteristic wrinkled, dry morphology and produced less EPS compared with the wild-type strain. The phenotype of this mutant and the fact that additional copies of rosR in strain Rt24.2(pBR24) caused an increase in the amount of EPS in culture supernatant indirectly confirmed positive regulation of EPS synthesis by RosR. The Rt24.2(pBR24) strain induced more pink nodules on clover roots than the parental strain and the weight of green part of plants was significantly higher compared with control plants (data not shown). A similar phenomenon was observed in the case of $R$. etli $\Delta$ ros $R$ complemented by the ros $R$ gene, which was more competitive than the parental strain (Bittinger et al. 1997). These data indicate a possible transcriptional activation of several symbiosis-related genes by the overproduced RosR protein. 


\section{MATERIALS AND METHODS}

Bacterial strains, plasmids, and growth conditions.

Bacterial strains and plasmids used in the present study are listed in Table 3. R. leguminosarum, $R$. etli, and A. tumefaciens strains were grown in 79CA medium with $1 \%$ mannitol or $1 \%$ glycerol as carbon source at $28^{\circ} \mathrm{C}$ (Vincent 1970). E. coli strains typically were grown in Luria-Bertani (LB) medium at $37^{\circ} \mathrm{C}$ (Sambrook et al. 1989). To study the expression of rosR in the Rhizobium spp. or E. coli, the strains were cultured for $24 \mathrm{~h}$ in minimal M1 medium (Sambrook et al. 1989) supplemented with $1 \%$ mannitol or glucose, and vitamin solution at $2 \mathrm{ml} /$ liter, prepared according to Brown and Dilworth (1975). Antibiotics were supplemented as required at the following final concentrations: for E. coli, kanamycin at 25 or $40 \mu \mathrm{g} \mathrm{ml}^{-1}$, ampicillin at $100 \mu \mathrm{g} \mathrm{ml}^{-1}$, tetracycline at $10 \mu \mathrm{g} \mathrm{ml}^{-1}$, and gentamicin at $10 \mu \mathrm{g}$ $\mathrm{ml}^{-1}$; and for Rhizobium and Agrobacterium spp., streptomycin at $200 \mu \mathrm{g} \mathrm{ml}^{-1}$, nalidixic acid at $40 \mu \mathrm{g} \mathrm{ml}^{-1}$, tetracycline at $10 \mu \mathrm{g}$ $\mathrm{ml}^{-1}$, gentamicin at $10 \mu \mathrm{g} \mathrm{ml}^{-1}$, and kanamycin at $40 \mu \mathrm{g} \mathrm{ml}^{-1}$.

Complementation tests were carry out by triparental conjugation (Figurski and Helinski 1979) using pRC24 plasmid bearing rosR of Rt24.2 as donor and $R$. etli CE3 $\Delta$ ros $R, S$. meliloti 3131 mucR, or A. tumefaciens NTR1 rosR mutant strains as recipients. Exconjugants were selected on 79CA medium supplemented with the appropriate antibiotics.

\section{DNA methods.}

Standard techniques were used for plasmid isolation, restriction enzyme digestion, ligation, DNA cloning, transformation, and agarose gel electrophoresis (Sambrook et al. 1989). Sequencing was performed using the BigDye terminator cycle sequencing kit (Applied Biosystems, Foster City, CA, U.S.A.) and the ABI Prism 310 sequencer. Database searches were done with the BLAST and FASTA programs available from the National Center for Biotechnology Information (Bethesda, MD, U.S.A.) and European Bioinformatic Institute (Hinxton, U.K.). The putative promoter sequences were predicted using Neural Network Promoter prediction at the Berkeley Drosophila Genome Project.

\section{Cloning of rosR gene.}

Genomic fragments of Rt24.2 and RtTA1 containing the entire $\operatorname{ros} R \mathrm{ORF}$ were amplified using the following primers: forward, RosA 5'-GCGGATCCGCGACTTTACCAGATTTA3' for Rt24.2; forward, RosB 5'-GTCACGCTCTTCGGAATT CAGGGGT-3' for RtTA1; and reverse, RosD 5'-TCGGATCCT GTCGGCAAAGCATAAGA-3' for both Rt24.2 and RtTA1 strains. The introduced $B a m \mathrm{HI}$ and EcoRI recognition sites are underlined. The 1,174-bp PCR product for Rt24.2 and 856-bp fragment for RtTA1 were cloned into the respective sites of pUC19 vector resulting in pB31 and pB35 plasmid, respectively. The inserts of $\mathrm{pB} 31$ and $\mathrm{pB} 35$ containing the entire ros $R$ genes were sequenced. $\operatorname{ros} R$ Rt 24.2 and RtTA1 sequences are available in GenBank database under accession numbers AY683453 and AY683454, respectively.

\section{Construction of plasmids with nested deletions of the $\operatorname{ros} R$ promoter region.}

To construct the plasmids with deletions of the ros $R$ promoter region, plasmid pMP220 carrying a promoterless lacZ gene was used. For each 5 '-end deletion fusion, an upstream primer for the putative promoter region of $\operatorname{ros} R$, with introduced EcoRI restriction site, and the common reverse primer $\mathrm{RR} 1$, which annealed within the coding sequence of $\operatorname{ros} R$ with introduced $X b a \mathrm{I}$ restriction site, were used to amplify DNA fragments from $\mathrm{pB} 31$. For construction of $3^{\prime}$-end deletion fusions, common $\mathrm{pEP} 1$ primer and a set of reverse ( $\mathrm{pEP} 8$ to pEP12) primers were used (Table 4). The PCR products were digested with $E c o$ RI and $X b a I$ restriction enzymes and inserted between the EcoRI and $X b a I$ sites of pMP220 plasmid, resulting in plasmids $\mathrm{pEP} 0$ to $\mathrm{pEP} 12$ containing nested deletions of ros $R$ promoter fused to a promoterless lac $Z$ gene. The constructed plasmids were transferred from $E$. coli DH5 $\alpha$ into $R$. leguminosarum bv. trifolii 24.2 by triparental conjugations. $\beta$ galactosidase activities were determined by the method of Miller (1972) and expressed in Miller units. The reported values are averages of three to six independent measurements.

\section{Mutagenesis of $\operatorname{ros} R$.}

The 1,100-bp fragment of pB31 plasmid was PCR amplified using $\mathrm{pEP} 1$ and RosD primers. PCR product was digested with EcoRI/BamHI enzymes, cloned into the respective sites of the suicide vector pK19mobGII, and E. coli S17-1 cells were transformed with this construct. Inserts of several recombinant plasmids were sequenced and, in the insert of the plasmid
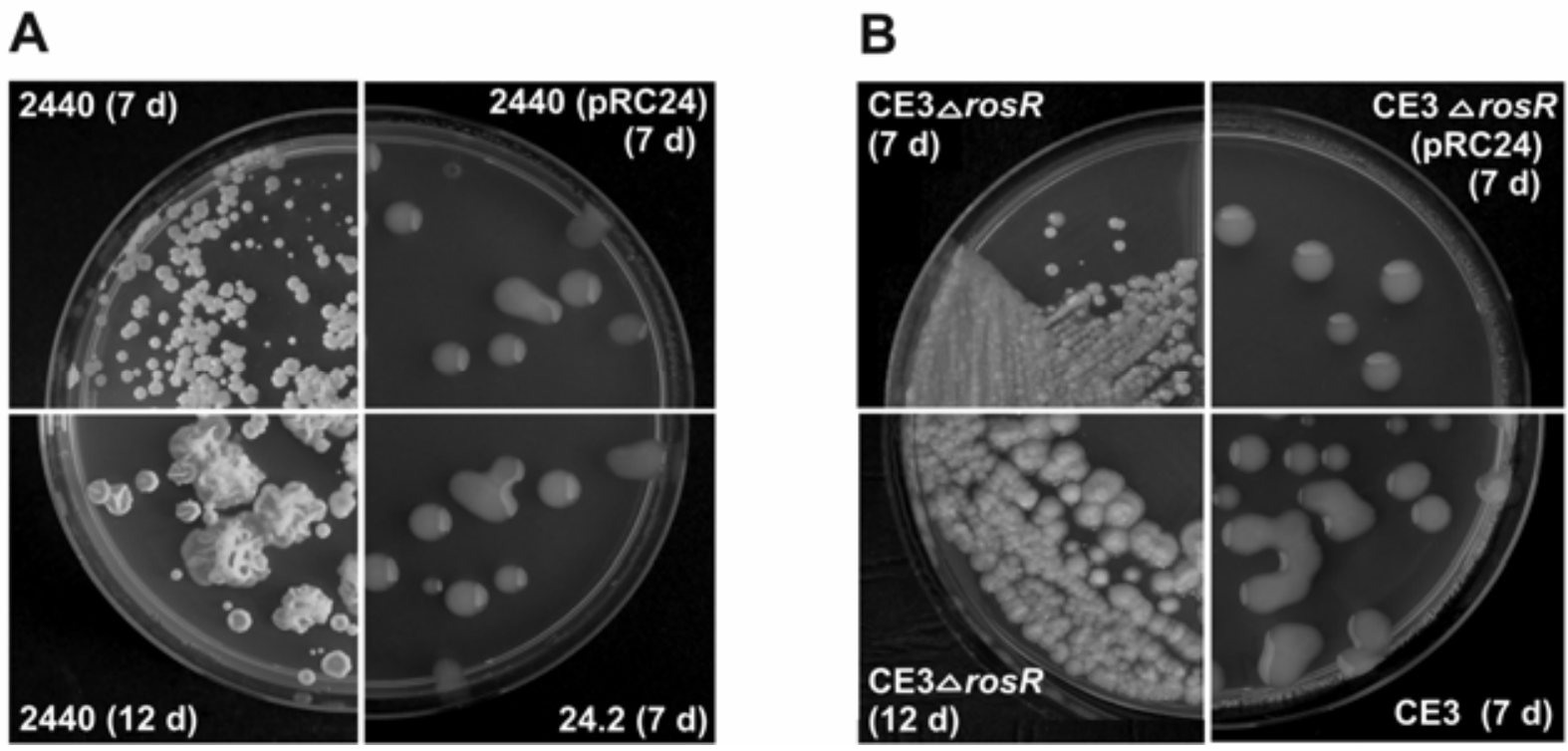

Fig. 9. Complementation of the A, Rhizobium leguminosarum bv. trifolii 2440 and $\mathbf{B}$, R. etli $\Delta \mathrm{CE} 3$ mutants by pRC24 plasmid containing the rosR gene of Rt24.2. Colonies were grown for 7 and 12 days on 79CA medium. 
named $\mathrm{pEPB} 12$, one nucleotide deletion $(\Delta \mathrm{C}$ in position +177 nt) was found which caused a frameshift mutation starting with the 60th amino acid residue. The nonsense codon (TGA) in position +277 was created which resulted in synthesis of a shorter putative RosR protein (92 instead of 143 aa) (Fig. 1). In addition, nucleotide substitutions resulting in L38P and D41E mutations of RosR were identified. pEPB12 was transferred from E. coli S17-1 to R. leguminosarum bv. trifolii 24.2 by conjugation and transconjugants were selected on 79CA medium with kanamycin and nalidixic acid. We isolated a clone, named Rt2440, with altered, wrinkled colony morphology. Recombination between pEPB12 and the R. leguminosarum bv. trifolii 24.2 ros $R$ gene was verified by PCR amplification using pEP1 and RosD primers with Rt2440 as a template and $P f u$ polymerase (Roche, Branchburg, NJ, U.S.A.) followed by sequencing of PCR product. Sequencing of the Rt 2440 PCR fragment confirmed the presence of the mutations mentioned above.

\section{Construction of ros $R$ containing expression plasmid.}

The ros $R$ gene was amplified by PCR from the pB31 plasmid as a template using forward primer EK1-5'-CCAGGAG AAAAAGGATCCCGGATA-3' with an introduced BamHI recognition site (underlined) and the reverse primer EK2-5'GTCGTCGACGCTTTCGAAAAAGCT-3' with an introduced SalI recognition site (underlined) and Ready Mix Taq PCR Reaction Mix (Sigma-Aldrich, St. Louis). The PCR product was digested with BamHI and SalI restriction enzymes and inserted into the corresponding sites in pUC19, yielding the pEK450 plasmid. The sequence of PCR product was verified by se-

Table 3. Bacterial strains and plasmids used in this study

\begin{tabular}{|c|c|c|}
\hline Strain or plasmid & Relevant characteristics ${ }^{a}$ & Sources or reference \\
\hline \multicolumn{3}{|c|}{$\begin{array}{l}\text { Rhizobium leguminosarum } \\
\text { bv. trifolii }\end{array}$} \\
\hline Rt24.2 & Wild type, Rif ${ }^{r}, \mathrm{Nx}^{\mathrm{r}}$ & Skorupska et al. 1995 \\
\hline RtTA1 & Wild type, Rif $^{\mathrm{r}}, \mathrm{Sm}^{\mathrm{r}}$ & Chakravorty et al. 1982 \\
\hline Rt2440 & Rt24.2 derivative carrying $\operatorname{ros} R$ with one nucleotide deletion & This work \\
\hline \multicolumn{3}{|c|}{ 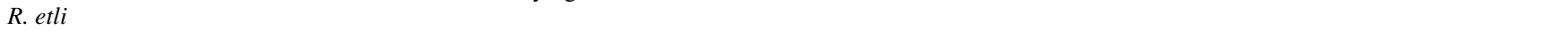 } \\
\hline CE3 & Spontaneous $\mathrm{Sm}^{\mathrm{r}}$ derivative of CFN42; $\mathrm{Sm}^{\mathrm{r}}, \mathrm{Nx}^{\mathrm{r}}$ & Noel et al. 1984 \\
\hline CE3 3 ros $R$ & CE3 with $\operatorname{ros} R$ deleted; $\mathrm{Sm}^{\mathrm{r}}, \mathrm{Nx}^{\mathrm{r}}$ & Bittinger et al. 1997 \\
\hline \multicolumn{3}{|c|}{ Sinorhizobium meliloti } \\
\hline $\mathrm{Rm} 2011$ & Wild type, $\mathrm{Sm}^{\mathrm{r}}$ & Casse et al. 1979 \\
\hline $\operatorname{Rm} 3131$ & $\operatorname{Rm} 2011$ тисR31::Tn5, $\mathrm{Sm}^{\mathrm{r}}, \mathrm{Km}^{\mathrm{r}}$ & Keller et al. 1995 \\
\hline \multicolumn{3}{|c|}{ Agrobacterium tumefaciens } \\
\hline NT1REB & Flagellum-free derivative of $\mathrm{C} 58, \mathrm{Sm}^{\mathrm{r}}$ & Lai and Kado 1998 \\
\hline NTR1 & NT1REB with ros mutation, $\mathrm{Sm}^{\mathrm{r}}$ & Cooley et al. 1991 \\
\hline \multicolumn{3}{|l|}{ Escherichia coli } \\
\hline DH5 $\alpha$ & 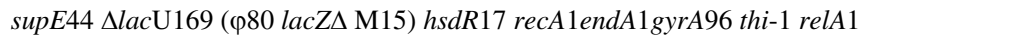 & Sambrook et al. 1989 \\
\hline M15 & $\mathrm{Lac}^{-}, \mathrm{Ara}^{-}, \mathrm{Gal}^{-}, \mathrm{Mtl}^{-}$ & Qiagen \\
\hline VH1000 & Derivative of MG1655, lacZ, lacI, pyrE ${ }^{+}$ & Gaal et al. 1997 \\
\hline VH1000cyaA & Derivative of VH1000, $\Delta c y a A:: \mathrm{Km}$ & Gaal et al. 1997 \\
\hline \multicolumn{3}{|l|}{ Plasmids } \\
\hline pUC19 & Cloning and sequencing vector, $\mathrm{Ap}^{\mathrm{r}}$ & Sambrook et al. 1989 \\
\hline pRK2013 & $\mathrm{Tra}^{+}$helper plasmid, $\mathrm{Km}^{\mathrm{r}}$ & Figurski, Helinski 1979 \\
\hline pRK7813 & IncP, $m o b$, Tra $^{-}$cosmid vector, $\mathrm{Tc}^{\mathrm{r}}$ & Stanley et al. 1987 \\
\hline pBBR1MCS-5 & $\mathrm{Mob}^{+}, l a c Z \alpha, \mathrm{Gm}^{\mathrm{r}}$ & Kovach et al. 1995 \\
\hline pREP4 & ori $\mathrm{p} 15 \mathrm{~A}, \mathrm{Km}^{\mathrm{r}}$, lacI $^{\mathrm{q}}$ & Qiagen \\
\hline pK19mobGII & $M o b, l a c Z \alpha$, gusA, $\mathrm{Km}^{\mathrm{r}}$ & Katzen et al. 1999 \\
\hline pQE-32 & ori ColE1, $\mathrm{Ap}^{\mathrm{r}}$, expression vector & Qiagen \\
\hline pMP220 & IncP, $m o b$, promoterless $l a c Z, \mathrm{Tc}^{\mathrm{r}}$ & Spaink et al. 1987 \\
\hline pB31 & pUC19 with 1,174-bp BamHI fragment containing $\operatorname{ros} R$ of Rt24.2 & This work \\
\hline pB35 & pUC19 with 856-bp EcoRI-BamHI fragment containing $\operatorname{ros} R$ of RtTA1 & This work \\
\hline pBR24 & pBBR1MCS-5 with 1,174-bp BamHI fragment containing rosR of Rt24.2 & This work \\
\hline $\mathrm{pRC} 24$ & pRK7813 with 1,174-bp BamHI fragment containing rosR of Rt24.2 & This work \\
\hline pEPB12 & $\begin{array}{l}\text { pK19mobGII with 1,100-bp EcoRI-BamHI fragment containing rosR of } 24.2 \text { with one } \\
\text { nucleotide deletion }\end{array}$ & This work \\
\hline $\mathrm{pEP0}$ & pMP220 carrying the -450 -bp upstream region to +243 bp of the ros $R$ coding region & This work \\
\hline pEP1 & pMP220 carrying the -403 -bp upstream region to +243 -bp fragment of $\operatorname{ros} R$ coding region & This work \\
\hline $\mathrm{pEP} 2$ & pMP220 carrying the $-357-b p$ upstream region to +243 -bp fragment of $\operatorname{ros} R$ coding region & This work \\
\hline pEP3 & pMP220 carrying the $-281-\mathrm{bp}$ upstream region to +243 -bp fragment of ros $R$ coding region & This work \\
\hline pEP3A & pMP220 carrying the -263 -bp upstream region to +243 -bp fragment of $\operatorname{ros} R$ coding region & This work \\
\hline pEP3B & pMP220 carrying the -250 -bp upstream region to +243 -bp fragment of ros $R$ coding region & This work \\
\hline pEP3C & pMP220 carrying the -235 -bp upstream region to +243 -bp fragment of ros $R$ coding region & This work \\
\hline pEP4 & pMP220 carrying the -219 -bp upstream region to +243 -bp fragment of $r o s R$ coding region & This work \\
\hline pEP5 & pMP220 carrying the -159 -bp upstream region to +243 -bp fragment of ros $R$ coding region & This work \\
\hline pEP6 & pMP220 carrying the -96 -bp upstream region to +243 -bp fragment of ros $R$ coding region & This work \\
\hline $\mathrm{pEP} 7$ & pMP220 carrying the -41 -bp upstream region to +243 -bp fragment of $r o s R$ coding region & This work \\
\hline pEP8 & pMP220 carrying the $-403-b p$ to $-32 \mathrm{bp}$ of $\operatorname{ros} R$ upstream region & This work \\
\hline $\mathrm{pEP} 9$ & pMP220 carrying the $-403-\mathrm{bp}$ to -185 bp of $\operatorname{ros} R$ upstream region & This work \\
\hline pEP10 & pMP220 carrying the -403 -bp to -232 bp of $\operatorname{ros} R$ upstream region & This work \\
\hline pEP11 & pMP220 carrying the $-403-b p$ to -268 bp of $\operatorname{ros} R$ upstream region & This work \\
\hline pEP12 & pMP220 carrying the $-403-\mathrm{bp}$ to -348 bp of $\operatorname{ros} R$ upstream region & This work \\
\hline pSF2 & pMP220 with one $1,084-b p$ SacI fragment carrying promoter region of pssA & Janczarek and Skorupska 2004 \\
\hline $\mathrm{pEK} 450$ & pUC19 with 450-bp BamHI-SalI fragment containing $\operatorname{ros} R$ of Rt24.2, Ap ${ }^{\mathrm{r}}$ & This work \\
\hline pQE450 & pQE32 with 450-bp BamHI-SalI fragment containing $\operatorname{ros} R$ of Rt24.2, Ap ${ }^{\mathrm{r}}$ & This work \\
\hline
\end{tabular}

${ }^{\mathrm{a}} \mathrm{Rif}^{\mathrm{r}}, \mathrm{Nx}^{\mathrm{r}}, \mathrm{Sm}^{\mathrm{r}}, \mathrm{Ap}^{\mathrm{r}}, \mathrm{Tc}^{\mathrm{r}}, \mathrm{Gm}^{\mathrm{r}}$, and $\mathrm{Km}^{\mathrm{r}}=$ resistant to rifampicin, nalidixic acid, streptomycin, ampicillin, tetracycline, gentamicin, and kanamycin, respectively. 
quencing. The insert then was subcloned into the expression vector pQE-32 (QIAexpress; Qiagen, Hilden, Germany), generating plasmid $\mathrm{pQE} 450$ for the overproduction of a recombinant RosR carrying an $\mathrm{N}$-terminal $\mathrm{His}_{6}$-tag.

\section{Primer extension analysis.}

Total RNA was isolated from $R$. leguminosarum bv. trifolii 24.2 cells using the Trizol reagent (Sigma-Aldrich) according to the manufacturer's instructions. RNA was quantitated by determining the absorbance at an optical density at $260 \mathrm{~nm}\left(\mathrm{OD}_{260}\right)$ and stored at $-80^{\circ} \mathrm{C}$. The $\operatorname{ros} R$ transcriptional start site was identified by an automated fluorescent primer extension method as was described by Lloyd and associates (2005). A 5'-FAMlabeled oligonucleotide primer (5'-CATTGCCGGTCGCTATAT CCGTCATA-3') complementary to a region near the $5^{\prime}$ end of the $\operatorname{ros} R$ gene (from -2 to $+25 \mathrm{bp}$ ) was used. RNA was treated with DNase I (Roche) before use. Primer extension reactions were carried out where FAM-labeled primer at a final concentration of 10 pmol was added to $20 \mu \mathrm{g}$ of total RNA in the final volume of $20 \mu \mathrm{l}$. The cDNA synthesis was performed in one step using AMV RT enzyme (Promega Corp., Madison, WI, U.S.A.) (Lloyd et al. 2005). Samples of FAM-labeled cDNA were separated on an ABI PRISM 3100 Genetic Analyzer (Applied Biosystems) capillary electrophoresis instrument using techniques and parameters suggested by the manufacturer. The ROX-500 size standards (Applied Biosystems) were included in each run to determine fragment lengths.

\section{Overproduction and purification of RosR protein.}

E. coli M15 carrying the plasmid pQE450 was grown in 200 $\mathrm{ml}$ of LB medium supplemented with ampicillin $\left(100 \mu \mathrm{g} \mathrm{ml}^{-1}\right)$

Table 4. DNA primers used in the construction of semi-nested deletion of the $\operatorname{ros} R$ upstream region fused with promoterless $l a c Z$ in plasmid $\mathrm{pMP} 220^{\mathrm{a}}$

\begin{tabular}{cl}
\hline Name of primer & \multicolumn{1}{c}{ Sequence of primers $\left(\mathbf{5}^{\prime} \mathbf{- \mathbf { 3 } ^ { \prime } )}\right.$} \\
\hline $\begin{array}{c}\text { Forward } \\
\text { pEP0 }\end{array}$ & GCGAATTCGCGACTTTACCAGATT \\
pEP1 & ATGCAAGAATTCTGCACAGGAAGC \\
pEP2 & AGCCCCTGAATTCTTCATCTGTCA \\
pEP3 & GGTATTTGGATTCCAAGTAGAGTTCT \\
pEP3A & GCAAGTAGAGTTCGAATTTGAATTAC \\
pEP3B & GTGAATTAGAATTCTACTGCTTCCAAG \\
pEP3C & TACTGCTTCGAATTCCCTCAGTTT \\
pEP4 & GTCCCTCAGTTTTGAATCTAATGTC \\
pEP5 & CGGTCAGGAATTCTAAGAACAGGT \\
pEP6 & TCGAAACAGGAATTCGATTCCTGC \\
pEP7 & GCGTGGAATTCAAAGGCCGTTTGA \\
Reverse & \\
RR1 1 & CGCATTCTAGACATGTGATCTGCT \\
pEP8 & AACGGCTCTAGACTGACACGCCAAA \\
pEP9 & TCATGCTCTAGACGATGGCCTCAGT \\
pEP10 & GAGGGATCTAGAAGCAGTACGATTGT \\
pEP11 & CAGAACTCTAGATGCATTTTCAAATACCATCG \\
pEP12 & TGACAGATCTAGAATTGAGGGGCTCT \\
\hline
\end{tabular}

${ }^{\text {a }}$ Sequences for the EcoRI and $\mathrm{XbaI}$ restriction sites are underlined. and kanamycin $\left(25 \mu \mathrm{g} \mathrm{ml}^{-1}\right)$ at $30^{\circ} \mathrm{C}$. When the culture had reached an $\mathrm{OD}_{600}$ of approximately 0.4 , the expression of $\operatorname{ros} R$ was induced by addition of isopropyl- $\beta$-D-thiogalactopyranoside (final concentration $1 \mathrm{mM}$ ). The cells were harvested 3 to $4 \mathrm{~h}$ postinduction and lysed in lysis buffer $\left(50 \mathrm{mM} \mathrm{NaH} \mathrm{PO}_{4}\right.$, $\mathrm{pH} 8.0,300 \mathrm{mM} \mathrm{NaCl}, 5 \mathrm{mM}$ imidazole, $1 \mathrm{mM}$ phenylmethylsulfonyl fluoride, and lysozyme at $1 \mathrm{mg} \mathrm{ml}^{-1}$ ) on ice for 30 min. Following this, the samples were sonicated on ice using six 10 -s bursts at 200 to $300 \mathrm{~W}$ with a 10 -s cooling period between each burst. Crude cell lysates were clarified by centrifugation at $10,000 \times g$ for $40 \mathrm{~min}$. The supernatant was applied to a nikiel-nitrilotriacetic acid resin (Ni-NTA) (Qiagen) and the (His) ${ }_{6}$ RosR protein was eluted from the column with 200 $\mathrm{mM}$ imidazole. Column fractions containing the (His) ${ }_{6}$ RosR protein were pooled, two times dialyzed against buffer $(20$ $\mathrm{mM}$ Tris- $\mathrm{HCl}, \mathrm{pH} 8.0,100 \mathrm{mM} \mathrm{NaCl}$, and $10 \% \mathrm{vol} / \mathrm{vol}$ glycerol) and stored at $-20^{\circ} \mathrm{C}$. Protein concentration was determined by the Bradford method using Bio-Rad Protein Assay (BioRad Laboratories, München, Germany). The purification yield was approximately $1.5 \mathrm{mg}$ of (His) ${ }_{6}$ RosR protein per $200 \mathrm{ml}$ of E. coli M15 culture.

\section{EMSA.}

For EMSA, DNA fragments of ros $R$ promoter matching the RosR-box sequence were amplified by PCR using plasmid pB31 as a template. The primers used for PCR amplification are listed in Table 5. The fragments were labeled at $3^{\prime}$ ends with DIG-11ddUTP and terminal transferase using DIG Gel Shift Kit (Roche), according to the manufacturer's instruction. Unlabeled specific competitor fragments were obtained by PCR amplification using the same primers. In a routine assay, DIG-labeled DNA fragments I and II were mixed with purified (His) ${ }_{6}$ RosR in reaction buffer containing $20 \mathrm{mM}$ Hepes, $\mathrm{pH}$ 7.6, $1 \mathrm{mM}$ EDTA, $10 \mathrm{mM}\left(\mathrm{NH}_{4}\right)_{2} \mathrm{SO}_{4}, 1 \mathrm{mM}$ dithiothreitol (DTT), $0.2 \% \mathrm{wt} / \mathrm{vol}$ Tween $20,30 \mathrm{mM} \mathrm{KCl}$, poly-L-lysine at $5 \mu \mathrm{g} \mathrm{ml}^{-1}$, and poly[d(IC)] at $0.5 \mu \mathrm{g} \mathrm{ml}^{-1}$ to a total volume of $20 \mu \mathrm{l}$. The reaction mixture was incubated for $15 \mathrm{~min}$ at $25^{\circ} \mathrm{C}$. In competition assays, (His) $)_{6}$ RosR protein was added to DIG-labeled DNA fragments in the presence of various concentrations of specific competitor DNA fragments. After incubation, the reaction mixtures were loaded onto a nondenaturing $5 \%$ polyacrylamide gel with $10 \%$ glycerol and resolved in Tris-glycine buffer (25 mM Tris, 190 mM glycine) supplemented with $5 \mathrm{mM} \mathrm{MgCl}_{2}, 1 \mathrm{mM}$ EDTA, and $0.1 \mathrm{mM}$ DTT at $7 \mathrm{~V} / \mathrm{cm}$ for $3 \mathrm{~h}$. DNA protein complexes were electrotransferred onto a nylon membrane and visualized by chemiluminescent detection according to the instruction manual of DIG Gel Shift Kit (Roche).

\section{Chemical cross-linking.}

For chemical cross-linking, $1 \mu \mathrm{g}$ of RosR protein in $50 \mathrm{mM}$ potassium phosphate buffer ( $\mathrm{pH}$ 7.6) was incubated for $15 \mathrm{~min}$ at room temperature with increasing concentration of glutaraldehyde $(0.01$ to $0.25 \%$, vol/vol). The reactions were stopped by addition of loading buffer, heated $\left(5 \mathrm{~min}\right.$ at $\left.95^{\circ} \mathrm{C}\right)$, and analyzed by SDS-PAGE.

Table 5. Primers used for polymerase chain reaction (PCR) of the DNA fragments used in electrophoretic mobility shift assays

\begin{tabular}{|c|c|c|c|}
\hline DNA & $\begin{array}{c}\text { Name of } \\
\text { primer }\end{array}$ & Sequence of primers $\left(5^{\prime}-3^{\prime}\right)$ & $\begin{array}{c}\text { Length of PCR } \\
\text { product (bp) }\end{array}$ \\
\hline \multirow[t]{2}{*}{ Fragment I with RosR-box of Rt24.2 } & M2 & TCGCCTGGATCCTGACGTAGTGGT & 185 \\
\hline & M4 & TCCTGGTAGGATCCTCAAACGGCCT & \\
\hline \multirow[t]{2}{*}{ Fragment II with RosR-box of Rt 24.2} & M5 & CAGTATAGGATCCGGTTACGCT & 78 \\
\hline & M6 & CGCAGGGATCCACCTTCTGTT & \\
\hline \multirow{2}{*}{ Fragment III with Ros-box of Agrobacterium tumefaciens NT1REB } & AT1 & GGTTGATCAGACCTTTGTTGGCCATG & 160 \\
\hline & AT2 & ATGAACGCCGCATCGAGCGATGTGAA & \\
\hline \multirow{2}{*}{ Fragment IV with MucR-box of Sinorhizobium meliloti 2011} & SM1 & AGTCTCCATCGCGAGATAGCGGTCGGTT & 158 \\
\hline & SM2 & GAGTTCATTGCTCGTACCGAGCGAAGTC & $\ldots$ \\
\hline
\end{tabular}




\section{Western immunoblotting.}

SDS-PAGE-separated proteins were electroblotted onto Immobilon P (polyvinylidene diflouride) membranes (Millipore, Bedford, MA, U.S.A.), and probed with mouse anti-His 5 tag antibodies (Qiagen), followed by alkaline phosphatase-conjugated anti-mouse immunoglobulin antibodies (Sigma-Aldrich). Bands were visualized with nitroblue tetrazolium chloride/5bromo-4-chloro-3-indolyl phosphate (Sigma-Aldrich).

\section{EPS isolation.}

For EPS isolation, 5-ml cultures of rhizobia were grown in 79CA medium with $0.5 \%$ glycerol for 3 days at $28^{\circ} \mathrm{C}$ in a rotary shaker. EPS was precipitated from culture supernatants with 10 volumes of $96 \%$ ethanol. The precipitate was collected by centrifugation, lyophilized, resolved in water, and analyzed for carbohydrates according to Loewus (1952). Total sugars content was calculated in glucose equivalents.

\section{Plant tests.}

Red clover (Trifolium pratense cv. Ulka) seed were surface sterilized, germinated, and grown as described previously (Skorupska et al. 1995). The clover plants were inspected for root nodule formation and, after 5 weeks, plants were harvested and green matter production was estimated by weighing the shoots.

\section{ACKNOWLEDGMENTS}

We thank J. Handelsman (University of Wisconsin, Madison, U.S.A.) for providing the $R$. etli CE3 and CE3 $\Delta$ ros $R$ strains. We are grateful to C. Kado (Davis Crown Gall Group, University of California, Davis, U.S.A.) for providing the NT1REB and NTR1 strains of A. tumefaciens, and A. Becker (Lehrstuhl für Genetic, Bielefeld University, Bielefeld, Germany) for providing the Rm2011 and Rm3131 strains of S. meliloti. We also thank R. Gourse (via G. Węgrzyn, Department of Molecular Biology, University of Gdańsk, Poland) for providing the E. coli VH1000 and VH1000cyaA strains. We thank M. Małek for excellent technical assistance. This work was supported by the Polish Committee for Scientific Research grant number 2 P04A 03426.

\section{LITERATURE CITED}

Araujo, R. S., Robleto, E. A., and Handelsman, J. 1994. A hydrophobic mutant of Rhizobium etli altered in nodulation competitiveness and growth in the rhizosphere. Appl. Environ. Microbiol. 60:1430-1436.

Barnett, M. J., and Long, S. R. 1997. Identification and characterization of a gene on Rhizobium meliloti pSymA, $s y r B$, that negatively affects $s y r M$ expression. Mol. Plant-Microbe Interact. 10:550-559.

Becker, A., and Pühler, A. 1998. Production of exopolysaccharides. Pages 97-118 in: Rhizobiaceae. H. P. Spaink, A. Kondorosi, and P. J. J. Hooykaas, eds. Kluwer Academic Publishers, Dordrecht, London.

Becker, A., Rüberg, S., Küster, H., Roxlau, A. A., Keller, M., Ivashina, T., Cheng, H., Walker, G. C., and Pühler, A. 1997. The 32-kilobase exp gene cluster of Rhizobium meliloti directing the biosynthesis of galactoglucan: Genetic organization and properties of the encoded gene products. J. Bacteriol. 179:1375-1384.

Berg, J. M., and Shi, Y. 1996. The galvanization of biology: A growing appreciation for the roles of zinc. Science 271:1081-1085.

Bertram-Drogatz, P. A., Rüberg, S., and Becker, A. 1997. The regulatory protein MucR binds to a short DNA region located upstream of the mucR coding region in Rhizobium meliloti. Mol. Gen. Genet. 254:529-538.

Bertram-Drogatz, P. A., Quester, I., Becker, A., and Pühler, A. 1998. The Sinorhizobium meliloti MucR protein, which is essential for the production of high-molecular-weight succinoglycan exopolysaccharide, binds to short DNA regions upstream of exoH and exoY. Mol. Gen. Genet. 257:433-441.

Bittinger, M. A., and Handelsman, J. 2000. Identification of genes in the RosR regulon of Rhizobium etli. J. Bacteriol. 182:1706-1713.

Bittinger, M. A., Milner, J. L., Saville, B. J., and Handelsman J. 1997. $\operatorname{ros} R$, a determinant of nodulation competitiveness in Rhizobium etli. Mol. Plant-Microbe Interact. 10:180-186.

Borthakur, D., and Johnston, A. W. B. 1987. Sequence of psi, a gene of the symbiotic plasmid of Rhizobium phaseoli which inhibits exopolysaccharide synthesis and nodulation and demonstration that its transcrip- tion is inhibited by psr, another gene on the symbiotic plasmid. Mol. Gen. Genet. 207:149-154.

Borthakur, D., Barker, R. F., Latchford, J. W., Rossen, L., and Johnston, A. W. B. 1988. Analysis of pss genes of Rhizobium leguminosarum required for exopolysaccharide synthesis and nodulation of peas: Their primary structure and their interaction with psi and other nodulation genes. Mol. Gen. Genet. 213:155-162.

Brightwell, G., Hussain, H., Tiburtius, K., Yeoman, K. H., and Johnston, A. W. B. 1995. Pleiotropic effects of regulatory ros mutants of Agrobacterium radiobacter and their interaction with $\mathrm{Fe}$ and glucose. Mol. Plant-Microbe Interact. 8:747-754.

Brown, C. M., and Dilworth, M. J. 1975. Ammonia assimilation by Rhizobium cultures and bacteroids. J. Gen. Microbiol. 86:39-48.

Casse, F., Boucher, C., Julliot, J. S., Michel, M., and Denarie, J. 1979. Identification and characterization of large plasmids in Rhizobium meliloti using agarose gel electrophoresis. J. Gen. Microbiol. 113:229242.

Chakravorty, A. K., Zurkowski, W., Shine, J., and Rolfe, B. G. J. 1982 Symbiotic nitrogen fixation: Molecular cloning of Rhizobium genes involved in exopolysaccharide synthesis and effective nodulation. J. Mol. Appl. Genet. 1:585-596.

Chou, A. Y., Archdeacon, J., and Kado, C. I. 1998. Agrobacterium transcriptional regulator Ros is a prokaryotic zinc finger protein that regulates the plant oncogen ipt. Proc. Natl. Acad. Sci. U.S.A. 95:5293-5298.

Cooley, M. B., D'Souza, M. R., and Kado, C. I. 1991. The virC and virD operons of the Agrobacterium Ti plasmid are regulated by the ros chromosomal gene: Analysis of the cloned ros gene. J. Bacteriol. 173:26082616.

D'Souza-Ault, M. R., Cooley, M. B., and Kado, C. I. 1993. Analysis of the repressor of Agrobacterium virC and virD operons: molecular intercommunication between plasmid and chromosomal genes. J. Bacteriol. 175:3486-3490.

Dusha, I., Olah, B., Szegletes, Z., Erdei, L, and Kondorosi, A. 1999. syrM involved in the determination of the amount and ratio of the two forms of the acidic exopolysaccharide EPSI in Rhizobium meliloti. Mol. PlantMicrobe Interact. 12:755-765.

Ebright, R. H., Ebright, Y. W., and Gunasekera, A. 1989. Consensus DNA site for the Escherichia coli catabolite gene activator protein (CAP): CAP exhibits a 450-fold higher affinity for the consensus DNA site than for the E. coli iac DNA site. Nucleic Acids Res. 17(24):10295-10305.

Figurski, D. H., and Helinski, D. R. 1979. Replication of an origin-containing derivative of plasmid RK2 dependent on a plasmid function provided in trans. Proc. Natl. Acad. Sci. U.S.A. 76:1648-1652.

Gaal, T., Bartlett, M. S., Ross, W., Turnbough, C. L., Jr., and Gourse, R. L. 1997. Transcription regulation by initiating NTP concentration: rRNA synthesis in bacteria. Science 278:2092-2097.

Glazebrook, J., and Walker, G. C. 1989. A novel exopolysaccharide can function in place of the calcofluor-binding exopolysaccharide in nodulation of alfalfa by Rhizobium meliloti. Cell 56:661-672.

González, V., Santamaría, R. I., Bustos, P., Hernández-González, I., Medrano-Soto, A., Moreno-Hagelsieb, G., Chandra Janga, S., Ramírez, M. A., Jiménez-Jacinto, V., Collado-Vides, J., and Dávila, G. 2006. The partitioned Rhizobium etli genome: Genetic and metabolic redundancy in seven interacting replicons. Proc. Natl. Acad. Sci. U.S.A. 103:3834 3839.

Harman, J. G. 2001. Allosteric regulation of the cAMP receptor protein. Biochem. Biophys. Acta 1547:1-17.

Hollingsworth, R. I., Dazzo, F. B., Hallenga, K., and Musselman, B. 1988. The complete structure of the trifolim A lectin-binding capsular polysaccharide of Rhizobium trifolii 843. Carbohydr. Res. 172:97-112.

Janczarek, M., and Skorupska, A. 2004. Regulation of pssA and pssB gene expression in $R$. leguminosarum bv. trifolii in response to environmental factors. Antonie Leeuwenhook 85:217-227.

Katzen, F., Becker, A., Ielmini, M. V., Oddo, C. G., and Ielpi, L. 1999. New mobilizable vectors suitable for gene replacement in gram-negative bacteria and their use in mapping of the $3^{\prime}$ end of the Xanthomonas campestris pv. campestris gum operon. Appl. Environ. Microbiol. 65:278-282

Keller, M., Roxlau, A., Wenig, W. M., Schmidt, M., Quandt, J., Niehaus, K., Jording, D., Arnold, W., and Pühler A. 1995. Molecular analysis of the Rhizobium meliloti mucR gene regulating the biosynthesis of the exopolysaccharides succinoglycan and galactoglucan. Mol. PlantMicrobe Interact. 8:267-275.

Kolb, A., Busby, S., Buc, H., Garges, S., and Adhya, S. 1993. Transcriptional regulation by cAMP and its receptor protein. Annu. Rev. Biochem. 62:749-795.

Kovach, M. E., Elzer, P. H., Hill, D. S., Robertson, G. T., Farris, M. A., Roop, R. M., and Peterson, K. M. 1995. Four new derivatives of the broad-host-range cloning vector pBBR1MCS, carrying different antibiotic-resistance cassettes. Gene 166:175-176. 
Lai, E. M., and Kado, C. I. 1998. Processed VirB2 is the major subunit of the promiscuous pilus of Agrobacterium tumefaciens. J. Bacteriol. 180:2711-2717.

Latchford, J. W., Borthakur, D., and Johnston, A. W. B. 1991. The products of Rhizobium genes, psi and pss, which affect exopolysaccharide production, are associated with the bacterial cell surface. Mol. Microbiol. 5:2107-2114.

Lloyd, A. L., Marshall, B. J., and Mee, B. J. 2005. Identifying cloned Helicobacter pylori promoters by primer extension using a FAM-labelled primer and GeneScan analysis. J. Microbiol. Methods 60:291-298.

Loewus, F. A. 1952. Improvement in the anthrone method for determination of carbohydrates. Anal. Chem. 24:219.

Long, S. R. 2001. Genes and signals in the Rhizobium-legume symbiosis. Plant Physiol. 125:69-72.

Martin, M., Lloret, J., Sanchez-Contreras, M., Bonilla, I., and Rivilla, R. 2000. MucR is necessary for galactoglucan production in Sinorhizobium meliloti EFB1. Mol. Plant-Microbe Interact. 13:129-135.

Miller, J. H. 1972. Experiments in Molecular Genetics. Cold Spring Harbor Laboratory Press, Cold Spring Harbor, NY, U.S.A.

Mimmack, M. L., Borthakur, D., Jones, M. A., Downie, J. A., and Johnston, A. W. B. 1994a. The psi operon of Rhizobium leguminosarum biovar phaseoli: Identification of two genes whose products are located at the bacterial cell surface. Microbiology 140:1223-1229.

Mimmack, M. L., Hong, G. F., and Johnston, A. W. B. 1994b. Sequence and regulation of psrA, a gene on the Sym plasmid of Rhizobium leguminosarum biovar phaseoli which inhibits transcription of the psi genes. Microbiology 140:455-461.

Noel, K. D., Sanchez, A., Fernandez, L., Leemans, J., and Cevallos, M. A 1984. Rhizobium phaseoli symbiotic mutants with transposon Tn5 insertions. J. Bacteriol. 158:148-155.

Pabo, C., and Sauer, R. T. 1992. Transcription factors: Structural families and principles of DNA recognition. Annu. Rev. Biochem. 61:1053-1095.

Perret, X., Staehelin, C., and Broughton, W. 2000. Molecular basis of symbiotic promiscuity. Microbiol. Mol. Biol. Rev. 64:180-201.

Pollock, T. J., van Workum, W. A. T., Thorne, L., Mikolajczak, M. J., Yamazaki, M., Kijne, J. W., and Armentrout, R. W. 1998. Assignment of biochemical functions to glycosyl transferase genes which are essential for biosynthesis of exopolysaccharides in Sphingomonas strain S88 and Rhizobium leguminosarum. J. Bacteriol. 180:586-593.

Quester, I., and Becker, A. 2004. Four promoters subject to regulation by ExoR and PhoB direct transcription of the Sinorhizobium meliloti exoYFQ operon involved in the biosynthesis of succinoglycan. J. Mol. Microbiol. Biotechnol. 7:115-132.

Reeve, W. G., Dilworth, M. J., Tiwari, R. P., and Glenn, A. R. 1997. Regulation of exopolysaccharide production in Rhizobium leguminosarum biovar viciae WSM710 involves exoR. Microbiology 143:1951-1958.

Rolfe, B. G., Carlson, R. W., Ridge, R. W., Dazzo, R. W., Mateos, F. B., and Pankhurst, C. E. 1996. Defective infection and nodulation of clovers by exopolysaccharide mutants of Rhizobium leguminosarum bv. trifolii. Aust. J. Plant Physiol. 23:285-303.

Rüberg, S., Pühler, A., and Becker, A. 1999. Biosynthesis of the exopolysaccharide galactoglucan in Sinorhizobium meliloti is subject to a complex control by the phosphate-dependent regulator PhoB and the pro- teins ExpG and MucR. Microbiology 145:603-611.

Sambrook, J., Fritsch, E. F., and Maniatis, T. 1989. Molecular Cloning: A Laboratory Manual, 2nd ed. Cold Spring Harbor Laboratory Press, Cold Spring Harbor, NY, U.S.A.

Schell, M. A. 1993. Molecular biology of the LysR family of transcriptional regulators. Annu. Rev. Microbiol. 47:597-626.

Sharypova, L., Yurgel, S., Keller, M., Simarov, B., Pühler, A., and Becker A. 1999. The eff-482 locus of Sinorhizobium meliloti CXMI-105 that influences symbiotic effectiveness consists of three genes encoding an endoglycanase, a transcriptional regulator and an adenylate cyclase. Mol. Gen. Genet. 261:1032-1044.

Skorupska, A., Białek, U., Urbanik-Sypniewska, T., and van Lammeren, A. 1995. Two types of nodules induced on Trifolium pratense by mutants of Rhizobium leguminosarum bv. trifolii deficient in exopolysaccharide production. J. Plant Physiol. 147:93-100.

Skorupska, A., Janczarek, M., Marczak, M., Mazur, A., and Król, J. 2006. Rhizobial exopolysaccharides: Genetic control and symbiotic functions. Microb. Cell Fact. 16:7.

Spaink, H. P., Okker, R. J. H., Wijffelman, C. A., Pees, E., and Lugtenberg, B. J. J. 1987. Promoters in the nodulation region of the Rhizobium leguminosarum Sym plasmid pRL1JI. Plant Mol. Biol. 9:27-39.

Stanley, J., Dowling, D. N., Stucker, M., and Broughton W. J. 1987. Screening costramid libraries for chromosomal genes: An alternative interspecific hybridization method. FEMS (Fed. Eur. Microbiol. Soc.) Microbiol. Lett. 48:25-30.

Tellez-Sosa, J., Soberon, N., Vega-Segura, A., Torres-Marquez, M. E., and Cevallos, M. A. 2002. The Rhizobium etli cyaC product: Characterization of a novel adenylate cyclase class. J. Bacteriol. 184:3560-3568.

van Workum, W. A., Canter Cremers, H. C. J., Wijfjes, A. H. M., van der Kolk, C., Wijffelman, C. A., and Kijne, J. W. 1997. Cloning and characterization of four genes of Rhizobium leguminosarum bv. trifolii involved in exopolysaccharide production and nodulation. Mol. PlantMicrobe Interact. 10:290-301.

Vincent, J. M. 1970. A manual for the practical study of root nodule bacteria. International Biological Program Handbook No. 15. Blackwell Scientific Publications, Ltd., Oxford

Wösten, M. M. 1998. Eubacterial sigma-factors. FEMS (Fed. Eur. Microbiol. Soc.) Microbiol. Rev. 22:127-150.

Young, J. P., Crossman, L. C., Johnston, A. W., Thomson, N. R., Ghazoui, Z. F., Hull, K. H., Wexler, M., Curson, A. R., Todd, J. D., Poole, P. S. Mauchline, T. H., East, A. K., Quail, M. A., Churcher, C., Arrowsmith, C., Cherevach, I., Chillingworth, T., Clarke, K., Cronin, A., Davis, P., Praser, A., Hance, Z., Hauser, H., Jagels, K., Moule, S., Mungall, K., Norbertczak, H., Rabbinowitsch, E., Sanders, M., Simmonds, M., Whitehead, S., and Parkhill, J. 2006. The genome of Rhizobium leguminosarum has recognizable core and accessory components. Genome Biol. 7(4):R34

Zevenhuizen, L. P. T. M. 1986. Selective synthesis of polysaccharides by Rhizobium trifolii. FEMS (Fed. Eur. Microbiol. Soc.) Microbiol. Lett. 35:43-47.

Zhan, H. J., Levery, S. B., Lee, C. C., and Leigh J. A. 1989. A second exopolysaccharide of Rhizobium meliloti strain SU47 that can function in root nodule invasion. Proc. Natl. Acad. Sci. U.S.A. 86:3055-3059. 